\title{
Did the Individual Consent to the Risk of Harm? A Comparative Jurisdictional Analysis of Consent in Cases of Sexual Transmission/Exposure to HIV
}

Abstract: This article considers the necessary ingredients for an individual to consent to running the risk of the HIV virus being transmitted through high risk unprotected sexual intercourse. In order to achieve this aim an assessment of what should equate to a fully informed consent is evaluated. The article will provide a comparative jurisdictional analysis of the consent requirement in three particularised jurisdictions: England, Canada and the U.S.A. A comparison of relational judicial precepts will follow the discussion of extant law in each country. It will be established that few jurisdictions fully consider the requirements of a fully informed consent. The final part of the article will suggest a bespoke new legislative framework that will account for the circumstances that are necessary for an individual to provide a fully informed consent to the risk of acquiring the virus.

Keywords - HIV - Criminal - Consent - Comparative law - England

Introduction

The criminalisation of the sexual transmission of HIV is still fertile ground for academic extirpation. There have been many academic comments on the subject, but very little exploration of the parameters of a fully informed consent. ${ }^{1}$ The Law Commission have recently broached the sexual transmission of disease, but little attention was paid to the awareness of the complainant when consenting to

\footnotetext{
${ }^{1}$ For example see: Matthew Weait, 'Criminal Law and the Sexual Transmission of HIV: R v Dica' (2005) 68 Modern Law Review 121; Lisa Cherkassky, 'Being Informed: The Complexities of Knowledge, Deception and Consent when Transmitting HIV’ (2010) 74 Journal of Criminal Law 242; Samantha Ryan, 'Disclosure and HIV transmission’ (2015) 79 Journal of Criminal Law 395,
} 
unprotected intercourse with an HIV+ individual. ${ }^{2}$ It is evident that there is no true clarity on what ought to equate to a fully informed consent, and this is in need of clarification.

In order to address this question this paper focuses upon the parameters of a fully informed consent, and surveys three particularised countries. The current conceptualisation of consent is deficient in the majority of compared jurisdictions. Generally, the complainant is not afforded the opportunity to make a fully informed decision, as the basic premise asserts that the defence is fully operational once a complainant becomes 'aware' of the defendant's sero-status. ${ }^{3}$ The disclosing of one's sero-status does not signify that the complainant is attentive to the risk of the virus being transmitted, and this can be consider deficient.

The first section of this article will provide an effective definition of consent, within the context of HIV transmission/exposure, where factual and normative consent are considered. It will be demonstrated that both of these elements are necessary for there to be an informed consent. It is also essential to outline the parameters of a fully informed consent to be able proceed to evaluating the effectiveness or deficiency within the various legislative frameworks, and judicial precepts of the jurisdictions within this analysis.

The second section will set out the applicable law in England relational to consent and the transmission/exposure of HIV. The current position is that the consent of the

\footnotetext{
${ }^{2}$ Law Commission, Reform of the Offences Against the Person ( No 361, 2015)

${ }^{3} R$ v Dica [2004] EWCA Crim 1103, 3 All ER 593; R. v. Cuerrier, [1998] 2 SCR 371; Ark. Code Ann. § 5-14-123 (2017); Cal. Health \& Safety Code § 12029(2016) 
complainant may be a defence that can be put to the fact finder for deliberation. ${ }^{4}$ It will be demonstrated that the extant law does not provide any guidance, and that there has been no real consideration of normative consent. The subsequent part of the chapter considers the Canadian position where it will be demonstrated that consent can be a defence in these cases. ${ }^{5}$ However, the decisions that emanate from this jurisdiction have not explored the parameters of an effective consent. The position, like England, is that there may not be a fully informed consent on all occasions, and disclosure of one's sero-status is deemed sufficient for exculpation purposes.

The American position on consent will then be considered. This will highlight the divergent approaches to consent within the HIV State specific legislative frameworks. There are States that allow consent; ${ }^{6}$ those that require disclosure ${ }^{7}$ and those where there is no expressly stipulated provision on disclosure or consent. ${ }^{8}$ It will be shown that the majority of states do not take into account that the complainant 'ought' to be consenting to running the risk of infection. There are, however, states that have enacted legislation to accommodate normative consent, and thereby allow a fully informed consent.

The penultimate part of this work will provide the comparative analysis, and this identifies the similarities and differences within each designated jurisdiction. The comparison is divided into three distinct approaches: basic disclosure; quasienhanced disclosure; and enhanced disclosure. This terminology has never been

\footnotetext{
${ }^{4} R v$ Dica [2004] EWCA Crim 1103

${ }^{5}$ R. v. Cuerrier, [1998] 2 SCR 371

${ }^{6} 720$ Ill. Comp. Stat. § 5/12-5.01; Mo. Rev. Stat. § 191.677 (2016)

${ }^{7}$ Ark. Code Ann. § 5-14-123 (2017); Cal. Health \& Safety Code § 120291 (2017) and Ohio Rev. Code Ann. § 2903.11(2016)

${ }^{8}$ Wash. Rev. Code § 9A.36.011
} 
fully considered, and provides the framework for the proposed legislation. It is argued that in the majority of jurisdictions only consider factual consent, and that there is no true consideration of the significance of normative consent. Finally, the culmination of the chapter will provide an optimal model for a statutory footing that facilitates consent as a defence. This relies upon elements of Ohio's statutory provision, ensuring that an effective consent will be attained on all occasions. This bespoke legislative framework will provide clarity.

What should be considered as an effective consent?

Consenting to harm, or a risk of harm, seems to be a relatively undemanding concept to comprehend as an individual will either grant their consent or refuse to acquiesce. The simplicity of consent is delusional, ${ }^{9}$ and it is imperative to determine the constructional basis of valid consent within criminal HIV transmission/exposure cases. ${ }^{10}$ Generally, consent, that is legally permissible, transpires if a complainant permits the defendant to perform an act that will cause harm, or a risk of harm, to the consentor, and fits within the overarching public policy of the particularised legal system. ${ }^{11}$ Enabling that person to consent provides an individual with authority over the consentor to commit an act that would otherwise be criminal: subject, as stated, to overarching public policy considerations. ${ }^{12}$ For there to be sufficient consent, it must be given voluntarily by an individual who has made an informed choice. ${ }^{13}$ The

\footnotetext{
${ }^{9}$ See generally Peter Westen, The Logic of Consent (Ashgate Publishing 2004)

${ }^{10}$ See generally Matthew Weait and Yusef Azad, 'The Criminalization of HIV Transmission in England and Wales: Questions of Law and Policy (2005) 10 HIV/ AIDS Policy and Law Review 1 http://www.aidslaw.ca/site/wp-content/uploads/2013/04/EngWales_HIVReview10-2-E.pdf accessed 18th November 2017; John R. Spencer, 'Retrial for Reckless Infection' (2004) 154 New Law Journal 762

${ }^{11} R v$ Brown [1994] 1 A.C. 212

12 See generally Vera Bergelson, ‘Consent to Harm’ (2008) 28 Pace Law Review 683

13 ibid, 701
} 
complainant in these circumstances bestows the defendant with authorization to interfere with their bodily integrity. ${ }^{14}$

Witmer-Rich ${ }^{15}$ submits that a 'legally valid consent' consists of two elements. Firstly, there must be 'factual consent', in that the complainant acknowledges that they consent to allowing that person to embark upon the course of conduct that infringes upon their bodily integrity. ${ }^{16}$ This form of concurrence may be established either subjectively, performatively or as a hybrid of the subjective and performative models. ${ }^{17}$

The second element that ought to be satisfied is normative consent. ${ }^{18}$ 'Normative consent' reinforces the factual consent if three conditions are met. ${ }^{19}$ It is generally recognised that normative consent consists of knowledge, freedom and competence: however, the parameters of these conditions are contentious. ${ }^{20}$ If any of these ingredients are omitted then it is pertinent to assume that there cannot be a legally valid consent. ${ }^{21}$ Factual consent and normative consent will now considered.

Factual Consent: Subjective, Performative Or A Hybrid?

Factual consent is considered an essential, but insufficient, component to the defence of consent. ${ }^{22}$ It forms the foundation on which the court/fact-finder can determine whether the complainant has truly consented to normally prohibited conduct. There are three schools of thought on the construction of factual consent. ${ }^{23}$

\footnotetext{
${ }^{14}$ Jonathan Witmer-Rich, 'It's Good to be Autonomous: Prospective Consent, Retrospective Consent, and the Foundation of Consent in the Criminal Law’ (2011) 5 Criminal Law and Philosophy 377,397

15 ibid, 379

16 ibid, 379

${ }^{17}$ Alan Wertheimer 'What Is Consent? And is it Important?' (2000) 3 Buffalo Criminal Law Review 557, 566

${ }^{18}$ Witmer-Rich (n 14), 379

${ }^{19}$ Westen (n 9) 7

${ }^{20}$ ibid 7

${ }^{21}$ Joel Feinberg, Harm to Others (Oxford University Press 1984) 35-36 not a wrong if have given freely informed consent

${ }^{22}$ Westen (n 9) 25

${ }^{23}$ Wertheimer (n 17), 566 
The subjective view is promulgated upon the assumption that factual consent is attributed to the mental state of the complainant. ${ }^{24}$ Hurd, a proponent of the subjective model, suggests that the primary focus of factual consent must be assessed subjectively, as it affects the rights and duties of the individuals involved. ${ }^{25}$ By enabling subjective consent it demonstrates the 'exercise of free will'. ${ }^{26}$ It has been considered that it is the intention of the consentor to engage in the risky activity that enables an individual to cross any moral boundary or, alternatively, it is believed to be an intention to forego any moral objection to the interference. ${ }^{27}$ Both suggestions equate to a subjective assessment of factual consent, and neither need take preference over the other. This subjective analysis may seem appropriate in defining factual consent in certain types of criminal offence, for example rape, ${ }^{28}$ but may be incongruous to HIV transmission/exposure cases because the forming of the intention, by the complainant, to permit the defendant to interfere with their bodily integrity, may be deficient. How would a defendant be aware that the complainant was willing to embark upon acts of intimacy when the complainant has merely formed a mental agreement. More than a cognitive recognition can be expected as the defendant may be oblivious, without further indications, that the complainant agrees to any unprotected activity. ${ }^{29}$

The next variant of factual consent is the performative model. ${ }^{30}$ This advocates that the consentor must express that they acquiesce to the interference with their autonomy and bodily integrity. ${ }^{31}$ Under this proposition the agreement can originate via words or by actions. ${ }^{32}$ An expression of the agreement, it has been suggested, unequivocally conveys to the recipient that the complainant consents. ${ }^{33}$ To view factual consent exclusively upon the performative assumption would not be applicable to HIV transmission/exposure cases because the complainant must also

\footnotetext{
24 ibid, 566

${ }^{25}$ Heidi Hurd, 'The Moral Magic of Consent' (1996) 2 Legal Theory 121,124-25

${ }^{26}$ ibid,124-25; Larry Alexander, 'The Moral Magic of Consent (II)’ (1996) 2 Legal Theory 165

${ }^{27}$ Hurd (n 25) 124-25; Larry Alexander, The Moral Magic of Consent (II) (1996). 2 Legal Theory 165; Wertheimer (n 17), 567

${ }^{28}$ David P. Bryden, 'Redefining Rape' (2000) 3 Buffalo Criminal Law Review 317,355

${ }^{29}$ Wertheimer (n 17), 568

30 ibid, 566

30 ibid, 567

${ }^{31}$ ibid, 567

32 J.L. Austin, How to do Things with Words (Oxford University Press 1962) 99

${ }^{33}$ Wertheimer ( n17) 567 ; J.L. ibid, 99
} 
form an intention to agree to unprotected intercourse. Words or actions may not have this effect as what we say is not conclusive in these circumstances. The complainant may expressly consent to having intercourse, however, cognitive recognition of that acceptance is still essential.

The hybrid method takes into consideration both subjective and performative consent as part of an eclectic and evaluative duality of considerations. The blending of both of these elements may appease proponents of both persuasions. Westen ${ }^{34}$ proposes that performative consent is extrapolated from subjective factual consent as this is a core concept, ${ }^{35}$ thereby indicating that subjective factual consent is necessary. It is incomprehensible to understand how an individual can consent without mentally complying with any interference. An individual would only be able to express their factual consent after mentally acknowledging they acquiesce. It follows that a subjective agreement cannot be recognized unless there is some type of express accord, whether by words or actions. This is at its most evident in cases of consensual intercourse as there must be words or actions that signify that that person agrees to sexual intimacy. A combination of the subjective and performative consent clarifies the position of acquiescence by accommodating a mental agreement and some form of action by the complainant. This hybrid model is at its most apposite in criminal HIV transmission/exposure cases as a mental agreement, and the performative aspect, would conclusively embody that the complainant was factually consenting before normative consent can be taken into account.

The Essential Ingredients Of Normative Consent

It is generally recognised that the complainant's awareness must consist of knowledge, freedom and competence, but the parameters of these conditions are

\footnotetext{
${ }^{34}$ Westen (n 9)

${ }^{35}$ ibid 27 'it is a core concept of consent in that other conceptions of consent are conceptually derivative of it including factual expressive consent'
} 
contentious. $^{36}$ It is assumed, for current determination, that a complainant's knowledge will emanate from the traditional philosophical assumption of the term. ${ }^{37}$ If knowledge is to be portrayed in this manner then the complainant must be fully aware that the defendant is carrying the virus, and that there are risks of having the virus transmitted by having unprotected intercourse with an individual with that status. The complainant, under these conditions, must have that justified true belief in the defendant's HIV status, and the implications of having intercourse with that person, to be capable of consenting to running the risk of harm, because only then can it be said that they are fully aware. ${ }^{38}$

The freedom to make that choice signifies that the complainant must not be coerced into making a decision or be deceived. ${ }^{39}$ She must act autonomously without any external influence, otherwise the freedom of choice would be deficient. ${ }^{40} \mathrm{~A}$ truly liberal approach to consent endorses this freedom of choice and provides a complainant with the opportunity to forego their right to protect themselves from potential bodily harm. ${ }^{41}$ Any individual who consents must also be competent. ${ }^{42}$ For example, a mentally incapacitated, intoxicated or an under-age individual would be incapable to consent to running the risk of harm. Only if the three conditions of knowledge, freedom and competence coalesce can it eventuate that there is normative consent. ${ }^{43}$

The parameters of consent have been identified: namely that factual consent, and normative consent are essential elements for an individual to consent to running the risk of the transmission of HIV through unprotected sexual intercourse. ${ }^{44}$ It is now necessary to explore the extant substantive position in English law, and this will be critically analysed before evaluating the other comparator jurisdiction perspectives.

\footnotetext{
${ }^{36}$ ibid 7

${ }^{37}$ Proposition knowledge is traditionally considered to be a justified true belief in the existence of a fact: Jonathan Jenkins Ichikawa, and Matthias Steup , 'The Analysis of Knowledge' Stanford Encyclopaedia of Philosophy (Spring 2014 Edition) Edward N. Zalta (ed.), 1 http://plato.stanford.edu/archives/spr2014/entries/knowledge-analysis/ accessed $18^{\text {th }}$ November 2017

${ }^{38}$ Westen (n 9) $187-189$

${ }^{39}$ Westen (n 9) 180

${ }^{40}$ Joel Feinberg (n 21)116

${ }^{41}$ Ibid, 116

${ }^{42}$ Westen (n 9) 189-191

43 ibid 7

${ }^{44}$ For a discussion of informed consent in the context of HIV criminalisation see: Kim Shayo Buchanan, 'When Is HIV a

Crime? Sexuality, Gender and Consent’ (2015) 99 Minnesota Law Review 1231 Ar
} 
The US States have enacted specific legislation, whilst the Canadian approach is focused upon the general criminal law, and this provides an appropriate balance to the comparative analysis. In general terms, the ambit of consent as a defence in English law to the potential liability for non-fatal/sexual crimes has arisen in an ad hoc and solipsistic manner. The truism that hard cases make bad law ${ }^{45}$ is reflected in the uncertain moral barometer that governs this arena.

\section{The English Position on Consent and HIV Transmission}

Generally, common law and statute authorise a defendant to rely upon a complainant consenting to various non-fatal and sexual offences. ${ }^{46}$ In other circumstances the defence is not permissible. ${ }^{47}$ The contemporary premise, within the criminal transmission of HIV, is that the consent of the complainant can operate as a defence, and a soft paternalistic approach has been embraced. ${ }^{48}$ The defence is available to defendants who have transmitted the virus to a complainant, where that complainant has consented to unprotected intercourse knowing that that person has the virus. ${ }^{49}$ It is 'logical' to presume that the defendant could not have a reasonable belief of the complainant consenting to intercourse with an HIV+ individual if the defendant has not divulged their status. ${ }^{50}$

In Dica, ${ }^{51}$ the Court of Appeal expressly stipulated that consenting to intercourse does not imply that the complainant consented to intercourse with an HIV+ individual. In order for the complainant to fully consent she must be aware that the defendant has the virus; there must be a disclosure by the defendant of their serostatus. Consent may even be deemed to be a 'collateral issue' as disclosure can

\footnotetext{
${ }^{45} R v$ Brown [1994] 1 A.C. 212 (n 11); Slingsby [1995] Crim. LR 570; Wilson [1996] 2 Cr App R 241; Crim. LR 573; $R$ v Emmett (CA 18 June 1999)

${ }^{46} R$ v Brown [1994] 1 A.C. 212 (n 11); s74 Sexual Offences Act 2003

${ }^{47}$ ibid

${ }^{48} R$ v Dica [2004] EWCA Crim 1103

${ }^{49}$ ibid

${ }^{50}$ Lisa Cherkassky, 'Being Informed: The Complexities of Knowledge, Deception and Consent when Transmitting HIV' (2010) 74 Journal of Criminal Law 242, 248

51 ibid 
emerge as the crux of the matter. ${ }^{52}$ This is at its most evident when the complainant may acquire the requisite information from a source other than the defendant. ${ }^{53}$ The judiciary are unequivocal on this matter as Judge LJ promulgated examples whereby the complainant would acquire that knowledge from other sources. ${ }^{54}$

English Criminal Law Precepts: Facilitating The Defence Of Consent

In Dica, 55 the defendant was charged under section 20 of the Offences Against the Person Act 1861,56 and accused of transmitting HIV to two unsuspecting complainants. At trial, Dica sought to rely upon the consent of the complainants. It was stated that consent, even if it existed, was irrelevant. ${ }^{57}$ Justice Philpott relied upon Brown as the authority for this proposition. ${ }^{58}$ In Brown, ${ }^{59}$ the majority determined that where any harm was intended and/or caused there would be no consent unless it fell within a legitimate public policy exception. ${ }^{60}$ At the time of Dica's trial there was no exception for consensual unprotected intercourse where HIV was transmitted.

The decision in Brown ${ }^{61}$ was distinguished by the Court of Appeal in Dica, ${ }^{62}$ and delineated in terms of parameters and ambit. ${ }^{63}$ It was highlighted that the factual pattern of behaviour in Brown comprised of acts where there was the 'deliberate and intentional inflection of bodily harm', ${ }^{64}$ whereas Dica concerned consensual intercourse:

\footnotetext{
${ }^{52}$ Samantha Ryan, 'Disclosure and HIV transmission' (2015) 79 Journal of Criminal Law 395,399

${ }^{53}$ R. v Konzani [2005] EWCA Crim 706 [2005] 2 Cr. App. R. 14[44]

${ }^{54}$ ibid

${ }^{55} R$ v Dica [2004] EWCA Crim 1103

${ }^{56}$ Offences Against the Person Act 1861 s20. Whosoever shall unlawfully and maliciously wound or inflict any grievous bodily harm upon any other person, either with or without any weapon or instrument, shall be guilty of a misdemeanor (sic), and being convicted thereof shall be liable to be kept in penal servitude

${ }^{57} R v$ Dica [2004] EWCA Crim 1103[13]

${ }^{58}$ ibid

${ }^{59} R v$ Brown [1994] 1 A.C. 212 (n 11)

${ }^{60}$ ibid 234

${ }^{61}$ ibid

${ }^{62} R$ v Dica [2004] EWCA Crim 1103

63 ibid [46]

${ }^{64}$ ibid [45] 
"It does not follow from them, and they do not suggest, that consensual acts of sexual intercourse are unlawful merely because there may be a known risk to the health of one or other participant."65

Clearly, consensual unprotected intercourse, and 'running of the risk' were the pivotal issues that enabled the defence of consent to be galvanised, or not, in terms of informed consent. Cherskassky ${ }^{66}$ proposes that by delineating the running of the risk to the contrary position of policy, advocated in Brown, the case 'drew an interesting line regarding consent and HIV transmission'.67 If unprotected sexual intercourse between two consenting adults, meant that the virus would always be transmitted, then the defence may not have been permitted, and the policy decisions and construct adopted by the majority in Brown might have prevailed in HIV transmission precedents.

Judge LJ in Dica impliedly endorsed running the risk as one of the 'good reasons' that were set out in Brown. ${ }^{68}$ The rationale of the dicta has been questioned as it has been suggested that permitting an individual to consent to be infected with a potentially deadly virus can never be a 'good reason'. 69 It is not consent to being infected with the virus that was being endorsed; it is the running the risk of infection to which the informed complainant would be autonomously consenting via 'lawful' sexual intercourse. Throughout the judgment, acknowledgement of the risk was recognised. Judge LJ did state that:

"if the appellant concealed the truth about his condition from them, and therefore kept them in ignorance of it, there was no reason for them to think that they were running any risk of infection, and they were not consenting to it. On this basis, there

\footnotetext{
65 ibid [46]

${ }^{66}$ Cherkassky ( n 50)

${ }^{67}$ ibid, 248

${ }^{68} R$ v Dica [2004] EWCA Crim 1103[46]

${ }^{69}$ George R. Mawhinney, ‘To be Ill or to Kill: The Criminality of Contagion’ (2013) Journal of Criminal Law 202, 207
} 
would be no consent sufficient in law to provide the appellant with a defence to the charge under s.20."70

The statement implies that if a defendant discloses their sero-status this would be a sufficient revelation to be able to rely upon the defence of consent. Yet a disclosure of this type fails to take into consideration whether the complainant was fully aware that unprotected intercourse would create a risk of infection. Spencer ${ }^{71}$ even suggests that the complainant must have full knowledge of the facts, ${ }^{72}$ and proposed that Dica struck the 'appropriate balance' as a defendant who does not disclose will be liable, whilst those who do disclose will not be accountable. ${ }^{73}$ This proposition indicates that disclosure of the HIV status is the primordial requirement, and that this factorisation will enable the defence of consent to operate; nothing of the risk associated with such activity needed to be established. It is presumed that a complainant would always be aware of the risk of transmission, but this is simply not the case. Allowing disclosure in isolation does not take into account statistics on the awareness of transmission routes. ${ }^{74} \mathrm{~A}$ 'significant minority' appear to be unaware that the virus can be transmitted via sexual intercourse ${ }^{75}$ It signifies that a naïve individual may be blissfully unaware of this risk associated with certain activities. If such a person is unaware then how could they be said to have fully consented to the risk of infection? This is not the realms of fantasy; for example, a complainant aged sixteen may not be fully aware that they were consenting to running the risk of infection, but they would still be competent to have unprotected intercourse with an HIV+ individual.

Konzani: The Complainant Being Aware Of The Risk Of Transmission Through Sexual Intercourse

\footnotetext{
${ }^{70}$ ibid [38]

71 John R. Spencer, 'Retrial for Reckless Infection' (2004) 154 New Law Journal 762,

72 ibid, 767

73 ibid; Cherkassky (n 50), 248

${ }^{74}$ National Aids Trust HIV Public Knowledge and Attitudes, 2014

$<$ http://www.nat.org.uk/sites/default/files/publications/Mori_2014_report_FINAL_0.pdf > accessed $18^{\text {th }}$ November 2017

${ }^{75}$ As above
} 
The lack of clarity emanating from Dica is also evident in the other leading case of Konzani. In Konzani, ${ }^{76}$ the defendant was accused of infecting three females with HIV. It was alleged that none of the complainants were aware of the defendant's sero-status. ${ }^{77}$ The defendant appealed on the basis that the complainants had consented to unprotected intercourse, and it could be implied that they had consented to running the risk of infection. ${ }^{78}$ It was claimed that the judge had misdirected the jury by removing the opportunity to contemplate whether the defendant may have had an honest belief that she had consented. ${ }^{79}$ The case addressed how a complainant can acquire knowledge of a defendant's sero-status, and seemed to clarify the parameters of consent. It was confirmed that any consent must be fully informed and that:

"the defendant is not to be convicted if there was, or may have been an informed consent by his sexual partner to the risk that he would transfer the HIV virus to her." 80

This connotes that the complainant must not only be aware of the status of the defendant, but also that they must be alert to the risks associated with unprotected intercourse. Any such assertion corresponds to, and contradicts elements of the dictum that can be derived from Dica. It is a disclosure where the complainant knows of the risk that the virus may be transmitted that ought to be considered appropriate. Konzani also raised the issue of implied consent and that inculcation requires further elaboration.

Konzani And The Complaint Impliedly Consenting To Intercourse With An HIV+ Individual

\footnotetext{
${ }^{76}$ R. v Konzani [2005] EWCA Crim 706 [2005] 2 Cr. App. R. 14

77 ibid [3]

${ }^{78}$ ibid [5]

${ }^{79}$ ibid [36]

${ }^{80}$ ibid [43]
} 
The judgment in Konzani, ${ }^{81}$ reiterated that any consent must be fully informed, but in total contrast stipulated conditions whereby consent could be implied, denoting that the defendant may potentially form an honest belief that the complainant is consenting to running the risk of becoming infected. Judge LJ opined how knowledge of the defendant's sero-status could be acquired, but afforded no indication as to how the knowledge of the risks associated with unprotected intercourse with an HIV+ individual could be obtained. ${ }^{82}$ His Lordship provided illustrations of when a complainant may acquire knowledge of the defendant's HIV status. It was recognised that the complainant could gain the requisite facts from a hospital environment or via a third party. ${ }^{83}$ This insinuates that the defendant would not have to participate in any declaration of their HIV status, thereby enabling implied consent to enter into the realms of HIV transmission. Authorising the consentor to acquiesce by acquiring knowledge from another source may be understood to have enhanced that person's autonomy. They may be making an informed choice, and it may be asserted that it is a free willed decision evading any coercion from the defendant. Contrarily, such information may be inadequate as the complainant may only discover the most basic of information. The judgment is contradictory by requiring an informed consent, then stipulating that the disclosure of HIV status, whether by the defendant or another party, was sufficient to establish that the complainant was willing to run the risk as nothing else needed to be adduced. ${ }^{84}$

Weait, ${ }^{85}$ presciently in light of the actual judgment, set out a liberal perspective on consent, extending the parameters of implied consent to circumstances where the complainant is aware of the risks:

"...the defence should be available because in each of these cases that person is aware of the risk of transmission. They may be ignorant of a partner's HIV positive status in the sense that this has not been disclosed to them by him, but to deny the

${ }^{85}$ Matthew Weait, 'Criminal Law and the Sexual Transmission of HIV: R v Dica' (2005) 68 Modern Law Review 121
} 
defence if there is in fact knowledge of the risk, and a willingness to accept it, would be tantamount to saying that the person infected bears no responsibility for their own sexual and physical health"86

It was suggested that under these conditions the complainant would potentially have knowledge of the defendant's HIV status, and thereby would be consenting to running the risk of transmission. Weait has subsequently stated that the examples promulgated in Konzani were not extensive and limited to situations where disclosure has effectively taken place. ${ }^{87}$ Ryan also suggests that the examples are 'limited'. ${ }^{88}$ The proposal advocated by Weait and Ryan extend the parameters of the defence to circumstances whereby a complainant is aware that there is a possibility of the defendant having the virus, and they have not disclosed their status to the complainant. 89 The term 'possibility' does not equate to actual awareness, and therefore is not actual knowledge. If there has been no disclosure by the defendant, it would be feasible for the complainant to envisage that the defendant did not have the virus. It seems that Weait and Ryan anticipate an extension of implied consent that would potentially sanction further deceitful conduct by the defendant, and place the onus upon the complainant. This is arguably incorrect as it would swing the pendulum too much towards the awareness of risk and disassociate consent from disclosure. A less onerous position, for culpability purposes, would stipulate that the complainant must not only know that the defendant has the virus, but also that the type of activity may run the risk of becoming infected. The onus ought to be on the defendant to disseminate the relevant facts; the issue of implied consent should be negated in these cases.

Judge LJ arguably erred in Konzani by yielding to certain pro-defendant concessions. Furthermore, acknowledging that the information may originate from

\footnotetext{
${ }^{86}$ ibid, 128

${ }^{87}$ Matthew Weait, 'Knowledge, Autonomy and Consent: R. v Konzani' (2005) Criminal Law Review 763, 768

${ }^{88}$ Ryan (n 52), 398

${ }^{89}$ Weait, 'Knowledge, Autonomy and Consent' (n 87), 768
} 
various sources, does not denote that the complainant would be aware that there may be risk of infection. ${ }^{90}$ Allowing an individual to rely upon the information emanating from a third party does not imply that the defendant would have an honest belief that the complainant was consenting to unprotected intercourse with a HIV+ individual, everything is speculative. This is an unfortunate element of the judgment as it enables a defendant to avoid conviction for culpable conduct. Enabling the knowledge of the virus to emanate from a third party permits a defendant to act with the appropriate mens rea, transmit the virus, and still evade liability for their conduct. This haphazard development of how the defence functions warrants more clarification. The 'loophole' allows a defendant to be reckless, whilst placing the onus upon the complainant. Cherkassky has cogently adumbrated in this regard that enabling the consent to derive from other parties, 'would render the defendant's knowledge of his own HIV status irrelevant, leading to the dangerous assumption that the assailant need not divulge his status at all.' 91 If the knowledge from a third party is to act as a defence that functions correctly then Cherkassky argues that the complainant must inform the defendant of their awareness. ${ }^{92}$ Reed and Cooper concurred with this overarching culpability proposition:

"Where the defence of consent is to operate, it should surely be limited to those situations where it removes the defendant's culpability and blameworthiness because he is aware that the victim has knowledge of the risk at the relevant time and is therefore consenting." 93

Even where the complainant discloses awareness of the defendant's condition it does not indicate a fully informed consent, but this may equate to a 'reluctant consent' that has very recently received appellate endorsement, albeit controversially in Watson, ${ }^{94}$ and falls firmly within the ambit of factual consent. Dodds

\footnotetext{
${ }^{90}$ Cherkassky (n 50), 255

${ }^{91}$ ibid, 253

${ }^{92}$ ibid

${ }^{93}$ Simon Cooper and Alan Reed, 'Informed Consent and the Transmission of Sexual Disease: Dadson Revivified' (2007) 71 Journal of Criminal Law 461, 464

${ }_{94} R v$ Watson [2015] EWCA Crim 559 [34]
} 
et $a l,{ }^{95}$ consider that disclosure is currently, a 'precondition for relying upon the defence but it is the consent to the risk that actually matters'. ${ }^{96} \mathrm{~A}$ basic disclosure is insufficient; it is the complainant being aware of there being a risk of transmission that fulfils the obligation that attains a fully informed consent. Only then will an essential constructional element of normative consent be achieved. There must be recognition that the complainant is aware that there was a risk of transmission of the disease.

The Konzani judgment emphasised the importance of there being a balance between public policy and autonomy, and that is why a fully informed consent was utilised. ${ }^{97}$ It is, therefore, clear that the consent of the complainant is a defence to the reckless transmission of HIV. An approach of this type evidently denotes a soft paternalistic interpretation of the criminalisation of HIV. It is uncertain whether the disclosure of HIV status is sufficient for the defendant to rely upon the complainant consenting to the risk. In Dica, ${ }^{98}$ it was suggested that disclosing an HIV status sufficed, but Judge LJ provided conflicting dicta throughout the judgment. Konzani appeared to imply that more was necessary. ${ }^{99}$ Numerous scholars have also identified that the crucial issue is what the complainant must 'know' to be able to provide a fully informed consent. ${ }^{100}$ The other important element is that implied consent has been enabled by Konzani, but the parameters have not been fully ascertained. It seems that what constitutes consent will need to be revisited by the judiciary. The English position on consent, as identified, may be contrasted with the Canadian perspectives to identify synchronicity or otherwise with normative consent.

\section{The Canadian Judiciary And The Requirement Of Consent And Disclosure In HIV Transmission/Exposure Cases}

\footnotetext{
${ }^{95}$ Catherine Dodds, Adam Bourne and Matthew Weait, 'Responses to Criminal Prosecutions for HIV Transmission among Gay Men with HIV in England and Wales' (2009) 17 Reproductive Health Matters 135

${ }^{96}$ ibid, 139

${ }^{97}$ R. v Konzani [2005] EWCA Crim 706 [2005] 2 Cr. App. R. 14 [42]

${ }^{98} R$ v Dica [2004] EWCA Crim 1103

${ }^{99}$ R. v Konzani [2005] EWCA Crim 706 [2005] 2 Cr. App. R. 14

${ }^{100}$ Cherkassky (n 50),, 253
} 
The current position, within the Canadian jurisdiction, is that consent to unprotected intercourse does not convey that that person has consented to unprotected intercourse with an HIV positive individual. ${ }^{101}$ There will only be a legally valid consent if the defendant, under certain conditions, discloses their status to the complainant; otherwise consenting to unprotected intercourse is considered to have been obtained by fraud. ${ }^{102}$ This does not take into account that the complainant may be unaware of the risk of the virus being transmitted. There is no obligation placed upon a defendant to disclose to any prospective sexual partner that there is a risk of virus being transmitted. ${ }^{103}$ It is assumed that the complainant would always be versed on the risks, and this may not be the case. Consent, in these circumstances may not transform into a fully informed consent.

The Judicial Precepts Of Canada And The Disclosure/ Consent Requirement

An agglomeration of appellate cases, ${ }^{104}$ before the Canadian Courts, have confirmed that there is no issue with the complainant consenting to unprotected intercourse with an HIV+ individual. It is when a defendant has to disclose their HIV status that has been the focus of the courts' deliberations. This quandary primarily surfaced in $R v$ Cuerrier. ${ }^{105}$ The complainant (KM) had embarked upon an 18 month relationship with Cuerrier. Cuerrier had already tested positive for the virus before embarking upon the relationship. At the beginning of the relationship Cuerrier and KM had discussed sexually transmitted diseases, but Cuerrier had specified that he had tested negative for HIV. ${ }^{106}$ Eventually, Cuerrier and the complainant were tested and Cuerrier was confirmed to be HIV positive. The complainant continued to have unprotected intercourse with him, but stated that the reason for this was so that he could not infect anyone else. Cuerrier then embarked upon a relationship with

\footnotetext{
${ }^{101}$ R. v. Cuerrier [1998] 2 SCR 371

102 ibid

${ }^{103}$ R. v. Cuerrier [1998] 2 SCR 371; $R$ v Mabior [2012] SCC 47

${ }^{104}$ For example see: $R$. $v$. Cuerrier [1998] 2 SCR 371; $R v$ Mabior [2012] SCC 47; $R v$ Williams [2003] 2 S.C.R. 134

${ }^{105}$ R. v. Cuerrier [1998] 2 SCR 371

106 ibid [77]
} 
another woman $(\mathrm{BH})$ where he had unprotected intercourse without disclosing his sero-status. He was charged with two offences of aggravated assault in relation to $\mathrm{KM}$ and $\mathrm{BH} .{ }^{107}$

It was unequivocally confirmed that consent to unprotected intercourse did not signify consent to unprotected intercourse with an infected person. It was unanimously confirmed that the fundamental issue that needed to be resolved in the case was whether the consent was obtained by fraud. The pre-Cuerrier position stipulated two types of fraud existed: fraud as to the act or fraud as to the person. ${ }^{108}$ Both of these definitions had been removed from the Canadian Criminal Code. ${ }^{109}$ This enabled the Court to sequentially extend the parameters of the law on fraud. ${ }^{110}$ Each member of the court was prepared to extend the boundaries of fraud to encompass other circumstances. ${ }^{111}$ The majority proposed that fraud, within a commercial context, was analogous to the current situation. ${ }^{112}$ It would be considered to be fraud in this circumstance if the defendant did not disclose important facts, and thereby caused a 'deprivation or risk of deprivation.'113 The defendant, not disclosing or concealing their HIV status, would constitute fraud. ${ }^{114}$ Cory $\mathrm{J}$ stated that:

"Without disclosure of HIV status there cannot be a true consent. The consent cannot simply be to have sexual intercourse. Rather it must be consent to have intercourse with a partner who is HIV-positive. True consent cannot be given if there has not been a disclosure by the accused of his HIV-positive status. A consent that is not based upon knowledge of the significant relevant factors is not a valid consent. ${ }^{115}$

\footnotetext{
${ }^{107}$ Criminal Code, RSC 1985, c C-46, s 265

${ }^{108}$ R. v. Cuerrier [1998] 2 SCR 371 [36]

${ }^{109}$ R. v. Cuerrier [1998] 2 SCR 371 [108]; $R$ v Mabior [2012] SCC 47 [40]

${ }^{110} R$. v. Cuerrier [1998] 2 SCR 371 [97] -[103]

111 ibid

112 Ibid [117]

113 ibid [116]

114 ibid [124]

115ibid [127]
} 
Cory J's dictum is potentially contradictory. Throughout the judgment it is stated that disclosure of HIV status is the requirement, and then contrastingly proposes that there cannot be consent unless the complainant is aware of 'significant relevant factors'. 'Significant relevant factors' indicate that an awareness of the risk is a necessary component that should be attributed to the complainant, and this would assist in that person being afforded the opportunity to provide an informed consent. An informed consent can be stated to be 'informed, voluntary, and decisionally capacitated consent', ${ }^{116}$ whereby all the relevant facts have been disseminated. Anything devoid of these 'significant relevant factors' would denote that there was no legally valid consent. Could or should 'significant relevant factors' be extended to the defendant enlightening the complainant about there being a risk of transmission?

It appears that the judgment is interpreted so that disclosure of HIV status is the only requirement that is expected of the defendant. Once disclosure has taken place it may be deemed that the complainant is consenting to the 'risk' of infection. Basic disclosure does not connote that the complainant is consenting to running the risk of infection, but the court seems to impute that the complainant is consequently aware of the possibility of the virus being transmitted. There is a presumption that a complainant accepts the risks that are associated with sexual activity with an HIV+ individual. ${ }^{117}$ This is an acceptance of factual consent, and not necessarily normative consent. A complainant cannot be understood to have truly consented if they are oblivious to the risk that the activity may pose. ${ }^{118}$ The judgment suggests that all complainants will be fully conversant with the risks that are associated with having unprotected intercourse with an HIV+ individual, and fails to take into consideration the significant minority. ${ }^{119}$ It seems that factual consent takes precedence, thereby excluding normative consent in these situations. It is conceded the awareness will not be relevant in all cases as the majority of individuals will be aware of the risk of

\footnotetext{
${ }^{116}$ Nir Eyal, 'Informed Consent’ Stanford Encyclopaedia of Philosophy (Fall 2012 Edition), Edward N. Zalta (ed.), URL= http://plato.stanford.edu/archives/fall2012/entries/informed-consent/ accessed $18^{\text {th }}$ November 2017

${ }^{117}$ John Flaherty, 'Clarifying the Duty to Warn in HIV Transference Cases’ (2008) 54 Criminal Law Quarterly 60, 65

${ }^{118}$ National Aids Trust (n 74)

119 ibid 
infection by having unprotected intercourse, but a significant minority are unaware of the modes of transmission.

The use of basic disclosure as the threshold appears to transcend all Supreme Court decisions. The Supreme Court have reiterated on a number of occasions that disclosure of one's status was the only requirement. In $R v D C, 120$ it was inferred that basic disclosure would be sufficient to ascertain that the complainant consented. ${ }^{121}$ An acceptance of basic disclosure as the requirement cannot be assumed, as the Supreme Court in $R \vee$ Mabior $^{122}$ appear to acknowledge that a complainant may withhold their consent if they were aware of the risk of harm. In Mabior, the defendant was charged with nine counts of aggravated sexual assault. The language used by the Court is at best convoluted:

"Failure to disclose (the dishonest act) amounts to fraud where the complainant would not have consented had he or she known the accused was HIV-positive, and where sexual contact poses a significant risk of or causes actual serious bodily harm (deprivation)." ${ }^{123}$

The dictum may have multiple interpretations. Firstly, that disclosure by the defendant is sufficient as it is stated the complainant would not have consented if they were aware of the defendant's sero-status. Alternatively, if the complainant was aware they would not have partaken in activities that posed a risk of serious harm. It seems that it is the former that takes preference as it was again presumed throughout the judgment that an individual would be aware of the risk of the virus being transmitted by consenting to unprotected intercourse with an HIV+ individual. Yet it should be the latter that is preferred as it demonstrates that the complainant would need an awareness of the risk.

\footnotetext{
${ }^{120} R$ v D.C.2012 SCC 48

121 ibid

${ }^{122} R$ v Mabior [2012] SCC 47

123 ibid [104]
} 
There has been no confirmation about the extent of informed consent. It has been presumed that disclosure, and acceptance of that disclosure, denotes that the complainant will be consenting to running the risk of infection. Grant ${ }^{124}$ presumes such a stance, but expresses that the complainant will always withhold their consent when the defendant's HIV status is revealed to them: 'It also assumes that the accused knows his or her HIV status and that his or her sexual partner will withhold consent once disclosure takes place.' 125

There can be no such assumption as all that is required is a basic disclosure. This signifies that consenting to intercourse with an HIV + individual is sufficient and consenting to the risk need not be taken into account. In these situations a complainant who is unaware of the risk will only be consenting to unprotected intercourse with an HIV+ individual. This perception may have been altered if a truly informed consent is required as there would be awareness that the virus could be transmitted. The case law places the assessment of the risk onto the defendant, thereby excluding a complainant from any consultation on the matter, and this cannot be justified.

The Supreme Court of Canada: Williams And An Implied Consent

In $R v$ Williams, ${ }^{126}$ the Supreme Court affirmed that a defence based upon an implied consent was not appropriate in HIV exposure/transmission cases. Here the defendant was charged with aggravated assault after he had infected an unsuspecting partner with the virus. The basis of the appeal centred upon the timing of the infection, and whether the defendant had infected the complainant before he became aware that he had the virus. It was argued that an essential ingredient of the offence had not been made out, as Williams could not have endangered the life of the complainant as she may have already been infected. It was held that a

\footnotetext{
${ }^{124}$ Isabel Grant, ‘The Prosecution of Non-disclosure of HIV in Canada: Time to Rethink Cuerrier'(2011) McGill Journal of Law and Health 7 
conviction of aggravated assault was unattainable as the court stipulated that there was an inability to determine when the complainant became infected. The alternative charge of attempted aggravated assault could be upheld. It was confirmed that an absence of consent for actus reus purposes is evaluated subjectively from the complainant's perspective. ${ }^{127}$ The court held that the complainant had not subjectively consented to having unprotected intercourse with an HIV+ individual, thereby excluding implied consent. It was clear that the Court were unwilling to extend the parameters of the defence of consent to encompass an implied consent.

The court applied the definition of consent from $R v$ Ewanchuk. ${ }^{128}$ In Ewanchuk, a case unrelated to HIV exposure, the defendant had been charged with sexual assault. It was the Crown's case that the defendant had intimately touched the complainant on a number of occasions. Each time that the complainant said 'no' the defendant refrained from the conduct. He then persisted to a more serious assault where the complainant stated that any acquiescence was out of fear. Ewanchuk argued a defence based upon implied consent, as it seemed to the defendant that the complainant had consented. It was held that there was no defence of implied consent as a complainant either consents or they do not consent thereby emphasising the importance of subjectivity. ${ }^{129}$

It is reasonable for the Court in Williams to follow the decision in Ewanchuk as a defendant must disclose their HIV status when there is a significant risk of serious bodily. ${ }^{130}$ The onus is on the defendant to confirm that they have the virus. If implied consent were to be assessed from any point other than the complainant's subjective state of mind, it could be cogently argued that a defendant would anticipate that the complainant had impliedly consented simply by engaging in unprotected intercourse. This would put the complainant in an onerous position, and would afford a defence to

\footnotetext{
127 ibid 134 [37]

${ }^{128} R v$ Ewanchuk [1999] 1 S.C. 330

${ }^{129} R v$ Ewanchuk [1999] 1 S.C. 330 [31]

${ }^{130}$ R. v. Cuerrier, [1998] 2 SCR 371
} 
individuals who did not consider it appropriate to disclose their status to prospective partners.

The utilisation of the ratio in Ewanchuk, ${ }^{131}$ and, thus, the exclusion of implied consent, has not been universally accepted. Stewart ${ }^{132}$ distinguished the case from cases of HIV transmission/exposure as Ewanchuk did not stipulate that the decision should be applied to non-sexual offences, and Williams was charged with aggravated assault. ${ }^{133}$ Indeed, this may prove an accurate contention, but the court did not exclude the utilisation of its interpretation of consent to other offences. The conclusive acceptance of the Ewanchuk approach can, and should, be relevant to any assault provisions ${ }^{134}$ as the fundamental issue that must be established is whether the complainant consented to the interference. This corresponds with the subjective nature of factual consent, and ensures that any acquiescence can begin to align to the fundamental elements of normative consent.

An implied consent defence may still be envisaged if the defendant discloses their sero-status, and the complainant stipulates that they consented, but would not have consented if they were aware of the risks. In these circumstances the complainant would have consented to intercourse with an individual who is HIV+, being unaware of the risk of transmission by having intercourse. The current position is that the courts recognize that if an individual consents to intercourse with a person who is $\mathrm{HIV+}$ then it is assumed that that individual accepts the risk. This may be inadequate, in some circumstances, and will not always accord to normative consent, thereby connoting an implied consent.

The current obfuscatory position of implied consent in extant Canadian law, and the palpable anomalies created, does not give the impression that this is the end of the

\footnotetext{
${ }^{131} R$ v Ewanchuk [1999] 1 S.C. 330

${ }^{132}$ Hamish Stewart, 'When Does Fraud Vitiate Consent? A Comment on R. v. Williams' (2004) 49 Criminal Law Review 144

133 ibid, 147

${ }^{134}$ Carissima Mathen and Michael Plaxton 'HIV, Consent and Criminal Wrongs' (2011) 57 Criminal Law Quarterly 464,482
} 
matter. Rawluck ${ }^{135}$ postulates that the decision of the Supreme Court in Mabior ${ }^{136}$ resurrected implied consent. Here it was proposed that if disclosure is not required the complainant had effectively consented to partaking in intercourse with an individual who was HIV positive. ${ }^{137}$ It is stated that the decision, 'fails to protect a person's right to choose who to have sex with...'. 138 If that is a precise account then the equivalent could be promulgated in relation to the test that was originally set out in Cuerrier. ${ }^{139}$ Rawluck appears to promote L'Heureux-Dubé J's development of the definitional construct of fraud, whereby total disclosure would be mandatory. This approach was unanimously excluded by the judiciary in Mabior as the "net of culpability would be cast too wide'. 140

Canada And The Judicial Preference Towards Factual Consent

As has been demonstrated by the critical evaluation above, the tenets of Canadian law affords and promotes disclosure, and this forms the basis of any defence to the charges that are presented. ${ }^{141}$ The jurisprudence from this jurisdiction facilitates a soft paternal inclination to this type of situation. If sexual intimacy follows disclosure it equates to the complainant consenting to having unprotected intercourse with an HIV+ individual. ${ }^{142}$ This requisite level can be considered to be a basic disclosure as a defendant is only expected to disclose their sero-status. No dissemination of further information is anticipated as the judiciary presume that the complainant will always be aware of the risks associated with having unprotected intercourse with an HIV+ defendant. The exclusion of implied consent for actus reus purposes is to be welcomed as the subjective awareness of the complainant is the pre-eminent preference. $^{143}$ It seems that a fully informed consent is secondary in Canada as

\footnotetext{
${ }^{135}$ Kevin Rawluk, 'HIV and Shared Responsibility: A Critical Evaluation of Mabior and DC’ (2013) 22 Dalhousie Journal of Legal Studies 21 ,

${ }^{136} R$ v Mabior [2012] SCC 47

${ }^{137}$ Rawluk (n 135), 24

138 ibid, 27; see also Lucinda Vandervort, 'HIV, Fraud, Non-disclosure, Consent and a Strake Choice: Mabior or Sexual Autonomy?’ (2013)

60 Criminal Law Quarterly 301, 312-13

${ }^{139}$ R. v. Cuerrier [1998] 2 SCR 371

${ }^{140} R$ v Mabior [2012] SCC 47 [67]

141 ibid

142 ibid

${ }^{143} R v$ Williams [2003] 2 S.C.R. 134
} 
disclosure takes precedence, thereby denoting that in certain situations factual consent will suffice.

The critique of Canadian law in relation to consent and HIV exposure/transmission has revealed discrepancies and confusion within extant doctrinal principles. Attention will now focus on consent and disclosure within the United States, and an examination of prevailing orthodoxy.

Consenting To Unprotected Intercourse With An HIV+ Individual and The Disclosure Of Ones' Sero-Status Within The United States

The Presidential Commission submitted that any States with specific criminal provisions should permit a defendant to be exculpated if they disclose their HIV status to prospective sexual partners, and thereby attain the consent of the complainant to run the risk of transmission. ${ }^{144}$ The majority of States, that are subsequently considered, have enacted legislation where disclosure or consent can exculpate the defendant. Disclosure, prima facie, is synonymous with consent as the majority of States have utilised either of these terms interchangeably. ${ }^{145}$ This has translated to an affirmation that a complainant has agreed to have unprotected intercourse with the defendant.

Alternative State Approaches to Consent and Exposure To HIV: The Putative Search for Uniformity

There are distinct advantages to utilising a specific statutory provision that authorises a defence based upon consensual activities with an HIV+ individual. States that have

\footnotetext{
144 The Presidential Commission on the Human Immunodeficiency Virus Epidemic Report (1988) 131

145 Ark. Code Ann. § 5-14-123 (2017); Cal. Health \& Safety Code § 120291 (2017); Ohio Rev. Code Ann. § 2903.11 (2016); 720 Ill. Comp. Stat. § 5/12-5.01 andMo. Rev. Stat. § 191.677 (2016)
} 
enacted legislation that permits consent or a defendant to disclose their status have implemented a soft paternalistic legislative framework. ${ }^{146}$ Enabling such convergence may protect a fully informed complainant by facilitating them with the possibility of exercising their right to act autonomously. ${ }^{147}$ Indeed, a soft paternal model can be more meritorious than enacting hard paternalistic legislation. ${ }^{148}$ The restriction of the defendant's opportunity to disclose, or retracting the complainant's right to consent to unprotected intercourse, would unduly interfere with the sexual autonomy and reproductive autonomy of both individuals. ${ }^{149}$

The allowance of a specific provision on HIV transmission/exposure necessitates legislative precision as this presumptively would ensure no contentious issues would subsequently ensue, and this may be why the MPC is vague on the matter. This 'precision' cannot be seen within U.S. State law as there is no uniform approach to the defence of consent in exposure/transmission cases. The provisions under consideration can be compartmentalised into three distinct considerations: currently, there are States that allow disclosure by the defendant to act as a defence; ${ }^{150}$ States that anticipate the consent of the complainant; ${ }^{151}$ and finally jurisdictions that have no express provision that exists in relation to consent or disclosure. ${ }^{152}$ The analysis will begin by a critique of the jurisdictions that require the defendant to disclose their status.

U.S State Law That Requires The Defendant To Disclose Their Sero-Status

\footnotetext{
146 Thaddeus Mason Pope, ‘Counting the Dragon’s Teeth and Claws: The Definition of Hard Paternalism’ (2004) 20 Georgia State University Law Review 659, 678

147 Witmer-Rich (n 14), 380

${ }^{148}$ For a discussion of hard parternalism see Pope (n 146)

149 Jed Rubenfield, 'The Riddle of Rape-by-Deception and the Myth of Sexual Autonomy’ (2013) 122 Yale Law Journal 1372,1383

150 Ark. Code Ann. § 5-14-123 (2017); Cal. Health \& Safety Code § 120291 (2017) (the Californian statutory provision will be repealed in 2018 and is used for illustrative purposes); Ohio Rev. Code Ann. § 2903.11 (2016)

151720 Ill. Comp. Stat. § 5/12-5.01 and Mo. Rev. Stat. § 191.677 (2016)

152 Wash. Rev. Code § 9A.36.011 (2014)
} 
The disclosure statutes can be allocated into two categories. At present, the majority of the specific legislatory provisions require disclosure of ones' sero-status. ${ }^{153} \mathrm{~A}$ further provision imposes more extensive conditions that can require an establishment of the awareness of the risk on the part of the complainant. ${ }^{154}$ The following exposition will firstly focus upon States that expect the defendant to disclosure their sero-status.

States That Require Basic Disclosure By The Defendant

The statutory provisions of Arkansas, ${ }^{155}$ and California ${ }^{156}$ compel a defendant to disclose their sero-status to prospective sexual partners. There is a lack of clarity therein as to the requisite level of knowledge that the complainant must possess in order to make an informed decision. ${ }^{157}$ The only expectation is disclosure of HIV status on the part of a defendant. Therefore, there is no obligation placed upon the defendant to ensure that the complainant is aware of the risk associated with the activity that they are to partake in, and this may be considered to be a major flaw with the overarching statutory framework.

Each of the relevant provisions under consideration stipulate that the defendant must inform the complainant that they have the virus. ${ }^{158}$ Thus, there is a presumption that any individual who consents to unprotected intercourse with a HIV+ individual consents to the risk of infection. This connotes that disclosure of HIV status is the threshold expectation: such informational dissemination may be termed a basic disclosure. A basic disclosure ignores any awareness by the complainant of the implications of having unprotected intercourse with an HIV + individual.

\footnotetext{
153 Ark. Code Ann. § 5-14-123 (2017); Cal. Health \& Safety Code § 120291 (2017)

${ }^{154}$ Ohio Rev. Code Ann. § 2903.11 (2016)

155 Ark. Code Ann. § 5-14-123 (2017);

${ }^{156}$ Cal. Health \& Safety Code § 120291 (2017);

${ }^{157}$ Ark. Code Ann. § 5-14-123 (b) (2012); Cal. Health \& Safety Code § 120291 (a) (2014)

${ }^{158}$ Ark. Code Ann. § 5-14-123 (b) (2012); Cal. Health \& Safety Code § 120291 (a) (2014)
} 
The Californian statutory provision ascribes a defendant with the opportunity to disclose their status. ${ }^{159}$ It is stated that:

“(a) Any person who exposes another to the human immunodeficiency virus (HIV) by engaging in unprotected sexual activity when the infected person knows at the time of the unprotected sex that he or she is infected with HIV, has not disclosed his or her HIV-positive status, and acts with the specific intent to infect the other person with HIV, is guilty of a felony punishable by imprisonment in the state prison for three, five, or eight years."160 (emphasis added)

There is no elucidation as to the extent of the required disclosure, and it may be presumed, as a result of the terminology utilised within the section, that the defendant expressly stating that he has the virus will suffice for exculpatory inculcations. Intrinsically, all that is required is a basic disclosure, and this does not denote a fully informed consent. As previously observed, not all complainants will be conscious of the risk associated with unprotected intercourse ${ }^{161}$, and this should be a cause for concern. Currently, within California, there are no cases to substantiate the effectual interpretation of this provision, but this may be attributed to the overriding mens rea requirement of the section. ${ }^{162}$

An incremental development of the determination of disclosure can be surveyed in Arkansas. ${ }^{163}$ The statutory provision instructs a carrier of the virus to 'inform' a potential sexual partner that they are $\mathrm{HIV}+{ }^{164}$ This connotes that once the complainant assents to intercourse, in the knowledge of the sero-status of the defendant, then the defendant cannot be accountable for exposing or transmitting the virus to that person.

\footnotetext{
159 Cal. Health \& Safety Code $\S 120291$ (a) (2014) needs updating this section will be repealed $1^{\text {st }}$ January 2018 and is for illartive puposes

${ }^{160}$ Cal. Health \& Safety Code $\S 120291$ (a) (2014)

${ }^{161}$ Refer to previous discussion in England

${ }^{162}$ Cal. Health \& Safety Code $\S 120291$ (a) (2014)

163 State $v$ Weaver 939 S.W.2d 31656 Ark. App. 104 (1997)

${ }^{164}$ Ark. Code Ann. § 5-14-123 (b) (2012) NEW needs replacing
} 
The issue of disclosure has not been extensively explored in Arkansas. In State $v$ Weaver, ${ }^{165}$ a case heard in the Court of Appeals of Arkansas, an issue in relation to disclosure did arise. The prosecution relied upon third party evidence to ascertain that the defendant had been unwilling to disclose his sero-status. ${ }^{166}$ This evidence was adduced to rebut the defendant's testimony. The third party specified that the defendant had informed him that he wanted to transmit the virus to as many people as possible. ${ }^{167}$ The Court held that there was no error by the judge for allowing the admission of this evidence. Although the case did not specifically address the issue of disclosure, and the parameters of factual or normative consent, it did denote that basic disclosure, and to a certain extent, factual consent, was the apposite level. By implication, it would seem that the extent of normative consent may be deficient in cases within Arkansas.

$K_{\text {Kaplan }}^{168}$ submits that the basic disclosure provisions are defective, and attention should focus on the awareness of risk. ${ }^{169}$ Allowing an enhancement of basic disclosure would correspond to the requirements of normative consent being fulfilled, on all occasions. This is all the more pertinent when there is a distinction to be drawn between consenting to unprotected intercourse with an $\mathrm{HIV}+$ individual, and consenting to having unprotected intercourse that carries the risk of being infected with HIV. ${ }^{170}$ An enhanced disclosure would ameliorate any discrepancies in a provision by ensuring that a complainant was fully aware of the risk of consenting to intercourse with an HIV + individual.

Ohio And A Quasi-Enhanced Disclosure

This can be seen in Ohio where an alternative to basic disclosure is inserted into the statutory provision. ${ }^{171}$ It is evident that basic disclosure ${ }^{172}$ will suffice, but the

\footnotetext{
165 State $v$ Weaver 939 S.W.2d 31656 Ark. App. 104 (1997)

${ }^{166}$ State $v$ Weaver 939 S.W.2d 31656 Ark. App. 104, 108 (1997)

167 State $v$ Weaver 939 S.W.2d 31656 Ark. App. 104, 108 (1997)

${ }^{168}$ Margo Kaplan, 'Rethinking HIV-Exposure Laws' (2012) 87 Indiana Law Journal 1517,

169 ibid, 1534

170 ibid, 1534

${ }^{171}$ Ohio Rev. Code Ann. § 2903.11 (b) (2014)
} 
provision conjoins supplementary ingredients to ensure that a complainant is fully alert to the circumstances. ${ }^{173}$ It is a condition that is activated if a complainant lacks the 'mental capacity' to be able to consent to the risks that can be associated with unprotected intercourse with an HIV+ individual. ${ }^{174}$ This infers that a fully informed consent is essential in all instances, and signifies that it is the capacity rather than the knowledge of the complainant that is relevant to normative consent. The provision still denotes that knowledge of the risk is relevant, as the assessment of the complainant's 'mental capacity' can be assessed subjectively or objectively. This obliquely places the onus onto the defendant that in some cases he may need to seek clarification that the complainant understands the implications of sexual contact with an HIV+ individual. ${ }^{175}$ This provision can been seen to some extent to reinforce the importance of normative consent as an essential component that empowers a complainant to provide a fully informed consent.

The use of disclosure as the requisite threshold has received judicial examination. In State $v$ Gonzalez, a case heard at the Court of Appeals of Ohio, the defendant contended, inter alia, that the statute was vague, and that there was no definition of disclosure within the provision. ${ }^{176}$ The court disregarded the argument and held that disclosure should be given its ordinary English dictionary meaning, and that verbal disclosure of the defendant's status would be adequate. ${ }^{177}$ The approach, endorsed by the court, equiparated and balanced the position of the disclosure defence as the English meaning is relatively undemanding, and basic disclosure, can and will, be sufficient if the conditions permit this to be appropriate. ${ }^{178}$ Unfortunately, there no assessment of the enhanced provisions of the statute. Minahan ${ }^{179}$ submits there are still prevailing issues, and the definition of disclosure has not been tested by other appellate courts. ${ }^{180}$ It seems that the court were satisfied with using the ordinary literal meaning that was attributed to 'disclosure' as no further appeal was pursued.

\footnotetext{
172 Ohio Rev. Code Ann. § 2903.11 (b) (1) (2016)

${ }^{173}$ Ohio Rev. Code Ann. § 2903.11 (b) (2) (2014)

${ }^{174}$ Ohio Rev. Code Ann. § 2903.11 (b) (2) (2014)

175 Ohio Rev. Code Ann. § 2903.11 (b) (2) (2014)

${ }^{176}$ State v. Gonzalez 796 N.E.2d 12154 Ohio App.3d 9, 21 (2003)

${ }^{177}$ State v. Gonzalez 796 N.E.2d 12154 Ohio App.3d 9, 22 (2003)

${ }^{178}$ State v. Gonzalez 796 N.E.2d 12154 Ohio App.3d 9, 22(2003)

${ }^{179}$ W. Thomas Minahan, 'Disclosure Before Exposure: A Review of Ohio's HIV Criminalization Statutes' (2009) 35 Ohio Northern University Law Review 83

180 ibid, 106
} 
The more contentious issue would be ascertaining whether a complainant had the capacity to fully understand the implications of unprotected intercourse with an HIV+ individual.

It is apparent from the preceding discussion that the identified States have not implemented any standardised approach to the requirement of disclosure. The preponderance of the jurisdictions examined require basic disclosure as the threshold for exculpation purposes. This does not imply that basic disclosure is the most apposite method. It is Ohio that exclusively anticipates that there may be occasions where basic disclosure will be deficient.

Tierney ${ }^{181}$ proposes that disclosure alone does not establish a fully informed consent: 'consent by the partner after full disclosure of the risks associated with the activity should be a defense. ${ }^{\prime 182}$ To acquire this requisite threshold there would need to be amplification of the risk of transmission via sexual contact. ${ }^{183}$ Further endorsement of an enhanced legislative framework originates from MacArthur ${ }^{184}$ who proposes that basic disclosure does not encapsulate all culpable behaviours and is 'underbreadth' as an unaccompanied basic disclosure would not furnish the complainant with essential information to determine the risk of transmission. ${ }^{185}$ This may not allow a complainant to make an informed choice of whether to consent to the risk of the virus being transmitted, but this would not always be the case. McGuire ${ }^{186}$ also questions basic disclosure provisions as they protect the defendant, and suggests that a fully informed consent should be the requisite approach to protect the complainant by ensuring that they have a sufficient awareness of the circumstances. ${ }^{187}$ As previously stated, in order for the complainant to fully consent they must have all of the relevant facts disclosed to them and this may include an

\footnotetext{
181 Thomas W. Tierney, 'Criminalizing the Sexual Transmission of HIV: An International Analysis (1992) 15 Hastings International and Comparative Law Review 475

182 ibid, 512

183 ibid, 498

${ }^{184}$ James B. McArthur, ‘As the Tide Turns: The Changing HIV/AIDS Epidemic and the Criminalization of HIV Exposure’ (2009) 94

Cornell Law Review 707,

185 ibid, 735-6

${ }^{186}$ Amy L. McGuire, 'Comment: Aids as a Weapon: Criminal Prosecution of HIV Exposure’ 36 Houston Law Review 1787

187 ibid, $1803-04$
} 
explanation that there is a risk of transmission. ${ }^{188}$ Having considered the disclosure provision It is now appropriate to evaluate legislation that has specified that the consent of the complainant will be the basis of a defence.

State Statutory Provisions That Require The Consent Of The Complainant

There are a number of States that have enacted soft paternalistic legislation. The provisions enable the defendant to evade liability if the complainant consents to having intercourse with that person knowing that they are HIV+, and that they will be exposed to the virus. It is evident that the requirement of these statutes is a fully informed consent. This can, and does, form the basis to ascertain whether the conditions of normative consent have been fulfilled. Lucidity prevails as the provisions denote that the complainant must be fully aware of the defendant having the virus, and also of the risk of the virus being transmitted through sexual contact. McGuire acknowledged that an informed consent may include an awareness of risk, ${ }^{189}$ and proposes that:

“...an effective HIV statute should include a defense of informed consent. The defendant should have to prove that she adequately informed her partner of her HIV infection and that her partner subsequently consented to engage in the high risk conduct."190

A truly informed consent should envisage an individual having the opportunity to assess the circumstances by being furnished with all of the facts. ${ }^{191}$ The extent of those facts may need to include the risk of transmission. Only then can the threshold for normative consent be fulfilled. An informed consent of this magnitude could

\footnotetext{
${ }^{188}$ National Aids Trust (n 74)

${ }^{189}$ McGuire (n 186), 1802-3:“This requirement of informed consent may impose a burden upon the defendant not only to disclose her HIV status to her partners, but also to educate them on the risks of transmission before engaging in any activity that exposes them to the virus." 190 ibid, 1814-15
} 
correspond to the MPC definition of consenting to a risk being reasonably foreseeable, but that section does not ordinarily address sexual activity, instead focusing on non-fatal offences. ${ }^{192}$ Enabling an efficiently constructed foundation for informed consent may promote disclosure as the defendant would be fully aware of the expectations of the statutory provision. Exculpation would follow if the defendant informs the complainant of their HIV status and that unprotected sexual intercourse runs the risks of becoming infected.

These states ${ }^{193}$ perceive that a basic disclosure will be defective, and that supplementary conditions are essential for there to be a fully informed consent. Such a provision, by way of illustration, is contained within Illinois' Penal Code. It is stated that:

"it is an affirmative defense that the person exposed knew the infected person was HIV positive, knew the action could result in infection, and consented with that knowledge." 194

The provision is lucid to the extent that an informed consent is the requirement. Nevertheless, the terminology attributed to the provision raises a number of impediments that must be overcome for a defendant to rely upon the complainant's consent. ${ }^{195}$ The complainant must know that the defendant is infected. There is no indication as to how the complainant could acquire that knowledge. Would such revelations have to emerge from the defendant or can that information emanate from a third party, for example the defendant's mother? Any information emanating from a third party may connote that the defendant can rely upon an implied consent, and this has not been scrutinised within the jurisdiction.

\footnotetext{
192 Tierney (n 181), 498

193720 Ill. Comp. Stat 5/12-5.01; N.D. Cent. Code § 12.1-20-17; Nev. Rev. Stat. § 201.205; Mo. Rev. Stat. § 191.677

194720 Ill. Comp. Stat 5/12-5.01

195720 Ill. Comp. Stat 5/12-5.01 (d)
} 
The second limb is more ambiguous. What is meant by "action"? Does this denote the type of sexual activity? Logically it can be presumed that it would relate to the sexual activities that are described within the statute. Once the awareness of these linguistic obstacles have been overcome, can a complainant give consent? The language that is used in this provision evidently stipulates that the complainant must give a fully informed consent. They must be fully aware of all of the facts and anything devoid of this will not suffice. There has been no exploration of the defence of consent by the appellate court of Illinois, to assist clarification of interpretative difficulties. In 1990, Herman ${ }^{196}$ prophetically stated that the Illinois provision was sufficiently robust to survive judicial scrutiny because of the availability of the defence of consent. ${ }^{197}$

The requirement of a fully informed consent can be surveyed within other statutory provisions. In Missouri's statute it is stated that a defendant will have a defence if a prospective partner has knowledge and consents to being exposed to the virus. ${ }^{198}$ An exposition of knowledge and consent excludes consent in isolation. It can be surmised that knowledge denotes the complainant being fully aware of the defendant having the virus, and with the knowledge that they will be exposed to the virus. In this context, the complainant will be making an informed choice, and this conforms to normative consent. In State $v$ Wilson, ${ }^{199}$ a case concerning statutory rape and other offences, the Supreme Court of Missouri Court confirmed that the statute stipulates that a defendant must disclose their status to any individual who they are planning on having intercourse with, but there was no elaboration as to raising that person's awareness of risk. ${ }^{200}$

The 'type' of consent has been confirmed before the appellate courts in Missouri to exclude an implied consent. In State $v$ Yonts, ${ }^{201}$ the complainant testified that she

\footnotetext{
${ }^{196}$ Donald H.J. Herman, 'Criminalizing Conduct Related to HIV Transmission (1990) 9 Saint Louis University Public Law Review 351

197 ibid, 375-6

${ }^{198}$ Mo. Rev. Stat. § 191.677 1(2) (2014)

${ }^{199}$ State v. Wilson 256 S.W.3d 58 (Mo. 2008)

${ }^{200}$ State $v$ Wilson 256 S.W.3d 58, 64 (Mo. 2008), 64

${ }^{201}$ State v Yonts 84 S.W.3d 516, (Mo. Ct. App. 2002)
} 
had heard rumours of the defendant having the virus and that the defendant had denied the assertions. The fact that she may have been aware of the defendant's status prior to any intimacy was not considered, and infers that an implied consent is irrelevant within this State. The disregard of the potential awareness of the complainant is obvious, as the statutory provision connotes that knowledge within the context of normative consent is required, and an implied consent does not achieve this gradation. It was confirmed by the Appellate Court that a defendant commits the offence if he exposes a sexual partner to the virus without their knowledge or consent at the time of the contact, ${ }^{202}$ thereby implying that disclosure must emanate from the defendant. The unfortunate incidental effect of the decision is that intricacies of 'knowledge' were not explored, and there was no clarity as to the complainant's 'awareness' of the risk of the virus being transmitted.

\section{Washington And The Lack Of Legislative Clarity}

Other jurisdictions do not expicilately state that consent or disclosure can act as a defence. One such state is Washington where the legislative template vis-à-vis HIV exposure is demarcated by the omission of any particularised section identifying a specific defence predicated upon disclosure or consent. ${ }^{203}$ It may be assumed that the consent of the complainant to sexual intimacy with an $\mathrm{HIV}+$ individual is irrelevant for culpability purposes. This exclusion of consent or disclosure, by the legislator, would denote that the State has acceded to a hard paternalistic legislative framework. The concerning element of this type of provision is that it indicates that a defendant may be expected to embark upon a life of abstinence from unprotected intercourse. The criminal provision of Washington has received societal endorsement, but negatively precludes fully consenting partners. Weiss submits that:

"Virginia's and Washington's statutes, then, are the only statutes that are designed so that they criminalize the "gift-giving"/"bug-chasing" phenomenon while not

\footnotetext{
202 State v Yonts 84 S.W.3d 516, 519 (Mo. Ct. App. 2002)

${ }^{203}$ Wash. Rev. Code § 9A.36.011(2014) Rev. Code Wash. (ARCW) § 9A.36.011 (2017)
} 
criminalizing accidental transmission of HIV between an HIV-positive partner and an informed partner."204

Weiss assumes that a defendant would not be accountable if their prospective partner was 'informed'. The assertion is problematic as there is nothing that can be extracted from the provision that specifies that there can be a defence of consent or disclosure. The vacuity of the provision may impinge upon a defendant who anticipated that the consent of a complainant would have been a defence. The absence of any expressly stated constructional definition of consent or disclosure is concerning. It implies that the defendant would be unable to rely upon consent, even if it was a purely voluntary sexual interaction with a fully informed complainant acting autonomously, and an individual's rights are potentially rendered nugatory.

The appellate cases, within Washington, may have presented some conciliation to patrons of a soft paternalistic inclination. ${ }^{205}$ In State $v$ Ferguson, ${ }^{206}$ a case heard in the Court of Appeals of Washington, the complainant had consented to protected intercourse in the knowledge that the defendant was HIV+. On the third occasion, the complainant stated that the defendant removed the condom without her knowledge, thereby vitiating the consent to protected intercourse. The defendant appealed, inter alia, on the basis that he should have been given the opportunity to raise the defence of consent. ${ }^{207}$ This provided the court with the means to clarify the parameters of consent, but the appellate court imparted conflicting statements on whether the consent of the complainant can act as a defence in exposure cases. It was first postulated that the Court would not clarify whether the defence could be utilised. ${ }^{208}$ The Court then proceeded to demonstrate, through case law, that consent can act as a defence, but declined to elaborate on whether consent could be an appropriate mechanism for exculpation in HIV cases. ${ }^{209}$ It was assumed by the

\footnotetext{
${ }^{204}$ Amanda Weiss, 'Criminalizing Consensual Transmission of HIV' (2006) the University of Chicago Legal Forum 389,393

${ }^{205}$ State v. Ferguson P.3d, 97 Wash.App. 1080, 1999 WL 1004992 (Wash.App. Div. 2); State v. Whitfield 134 P3d 1203 (2006) 132 Wash App 878

${ }^{206}$ State v. Ferguson P.3d, 97 Wash.App. 1080, 1999 WL 1004992 (Wash.App. Div. 2)

${ }^{207}$ State v. Ferguson P.3d, 97 Wash.App. 1080, 1999 WL 1004992 (Wash.App. Div. 2) 6

${ }^{208}$ State v. Ferguson P.3d, 97 Wash.App. 1080, 1999 WL 1004992 (Wash.App. Div. 2) 6

${ }^{209}$ State v. Ferguson P.3d, 97 Wash.App. 1080, 1999 WL 1004992 (Wash.App. Div. 2) 6-7
} 
Court, but they would not hold, that consent may be the basis of a defence in these cases. $^{210}$ The Court refused to do so as the defence of consent was deemed to be irrelevant to the case that was before the them. ${ }^{211}$ Thus, the parameters of factual consent or normative consent were not fully explored.

State $v$ Whitfield, ${ }^{212}$ provided incremental guidance on the utilisation of a defence of consent in Washington. In Whitfield, the defendant was charged with multiple assault charges, having had unprotected intercourse on a number of occasions. ${ }^{213}$ It was proposed that the defendant, by 'deliberately concealing his HIV status' assisted the prosecution in determining that he was acting with intent. ${ }^{214}$ The judgment did not expressly stipulate that the defence may be available, but implied that disclosure or consent may assist in exonerating a defendant as intent is an essential ingredient of the offence. ${ }^{215}$ The Court did provide some clarification by stating that there can be no consent unless the complainant is fully aware of the defendant's HIV status, but declined to confirm that it may form the basis of a defence to such a charge ${ }^{216}$ This may still be seen to have strengthened the utilisation of the defence, but the Court did not expressly stipulate any amplification on the requisites for a valid consent, thereby excluding any discourse on the awareness of the risk.

The Distinct Approaches to Disclosure and Consent Within The United States

A multitude of U.S. States have enacted a soft paternalistic legislative framework to the criminalisation of HIV transmission/exposure. There is a clear distinction between provisions that require disclosure, and those that necessitate the consent of the complainant. The legislative provisions that require disclosure appear to denote a more basic approach. In the majority of those provisions, the defendant is obliged

\footnotetext{
${ }^{210}$ State v. Ferguson P.3d, 97 Wash.App. 1080, 1999 WL 1004992 (Wash.App. Div. 2) 7

${ }^{211}$ State v. Ferguson P.3d, 97 Wash.App. 1080, 1999 WL 1004992 (Wash.App. Div. 2) 7

212 State v. Whitfield 134 P3d 1203 (2006) 132 Wash App 878

${ }^{213}$ State v. Whitfield 134 P3d 1203 (2006) 132 Wash App 878

214 State v. Whitfield 134 P3d 1203 (2006) 132 Wash App 878 [48]

${ }^{215}$ State v. Whitfield 134 P3d 1203 (2006) 132 Wash App 878 [57]

${ }^{216}$ State v. Whitfield 134 P3d 1203 (2006) 132 Wash App 878 [55]-[57]
} 
to disclose their sero-status, and this alone will be considered adequate for exculpation purposes. ${ }^{217}$ Basic disclosure is deficient, as not every complainant will appreciate the potential severity of the situation. ${ }^{218}$ For example, they may not be fully conversant to the risk of the virus being transferred through unprotected intercourse. This is only identified, within their disclosure provisions, by the State of Ohio, where the complainant must be aware of the risks to be able to provide a fully informed consent. 219

The provisions ${ }^{220}$ that require the consent of the complainant are more translucent than those that express disclosure. Each of those statutes necessitate an awareness of the defendant's HIV status that is conditional upon the complainant consenting to the risk of becoming infected with the virus. The provisions acknowledge that potential complainants are informed of the risk of the virus being transmitted, but fail to recognise that the majority of defendants would already be aware. The appellate cases within these indentified jurisdictions have not explored the provisions that expressly stated that the complainant must be aware the risk of infection, as the wording of the statute seems to be taken as a given. Beyond these particularised legal system approaches it is necessary to articulate a comparative juxtaposition of the extant law, to establish the similarities and differences in the approach to consent, and present preferred reform pathways.

\section{A Cross-Jurisdictional Analysis Of The Defences Of Consent And Disclosure}

It is evident from the aforementioned discussion that consent may negate otherwise culpable conduct. Allowing the defence of consent is advantageous for two reasons. It can, if the conditions permit, enable the complainant to make an informed choice and respect that individual's autonomy. The utilisation of the defence can also

\footnotetext{
217 Ark. Code Ann. § 5-14-123 (2017); Cal. Health \& Safety Code § 120291 (2017)

218 National Aids Trust (n 74)

219 Ohio Rev. Code Ann. § 2903.11 (2016)

220720 Ill. Comp. Stat. § 5/12-5.01; Mo. Rev. Stat. § 191.677 (2016)
} 
encourage a defendant to act in a responsible manner. By permitting consent, the majority of the jurisdictions considered have implemented a soft paternalistic approach to criminalising such proclivity. It is generally accepted that providing that the complainant is aware of the defendant's sero-status then there is a freedom to run the risk of becoming infected. This does not imply that there has been a uniform approach to consent. The utilisation of the defence does not denote that all of the jurisdictions specify the extent of the information that the defendant needs to disseminate for the defence to be fully operational. There are divergent approaches to the expectation of disclosure within the jurisdictions.

The Contrasting Levels Of Disclosure Within The Legal Systems Levels of Disclosure

The extent of the disclosure requirement is a crucial determinant that has received limited judicial or legislative scrutiny, and significant distinctions in this important respect can be drawn between England, Canada and the various U.S. State laws. The divergent levels of disclosure, and therefore consent, can be compartmentalised into three distinct groups: there are those jurisdictions that require basic disclosure, ${ }^{221}$ a quasi-enhanced disclosure; 222 and/or an enhanced disclosure. ${ }^{223} \mathrm{~A}$ basic disclosure compels the defendant to divulge that they have the virus, advocated and identified within the Canadian jurisdiction. ${ }^{224}$ The quasi-enhanced provision expects the defendant to disclose their sero-status, but the provision may exclude a defence of basic disclosure if the complainant is unaware of the risk of becoming infected and this is the approach that is adopted within the State of Ohio. ${ }^{225}$ The final alternative is an enhanced disclosure template that obliges the defendant to disclose their HIV status, and that there is a risk of infection being

\footnotetext{
${ }^{221} R$ v Dica [2004] EWCA Crim 1103; R. v. Cuerrier [1998] 2 SCR 371; Ark. Code Ann. § 5-14-123 (2017); Cal. Health \& Safety Code § 120291 (2017)

${ }^{222}$ Ohio Rev. Code Ann. § 2903.11 (2016)

223720 Ill. Comp. Stat. § 5/12-5.01; Mo. Rev. Stat. § 191.677 (2016)

${ }^{224}$ R. v. Cuerrier [1998] 2 SCR 371

${ }^{225}$ Ohio Rev. Code Ann. § 2903.11 (2016)
} 
transmitted.226 It is an altered quasi-enhanced model that is the preferred approach herein, and further reflective considerations in this regard are subsequently iterated.

An Analysis Of The Criminal Justice Systems That Require Basic Disclosure

As discussed above, the development of basic disclosure does not anticipate the defendant professing anything other than that they have the virus. This 'basic' disclosure is undemanding, and there are distinct advantages to allowing limited information to be disseminated. The requirement is relatively simple to adhere to, and it is unproblematic for the defendant and the complainant to substantiate that the relevant information had been communicated to the complainant, although in practice this can be a contentious issue, as previously stated. ${ }^{227}$

The English jurisdiction provides conflicting dicta on the utilisation of basic disclosure, and equiparation with more straitened enhanced disclosure. ${ }^{228}$ There is too much emphasis placed within the leading judgments on the complainant having the 'opportunity' to make an informed choice. ${ }^{229}$ There is obfuscation as to how a complainant would be able to cognitively formulate an informed choice. In Dica, ${ }^{230}$ it was inferred that a basic disclosure was the appropriate method of informing a complainant. ${ }^{231}$ It was presumed that once disclosure had transpired the complainant would know of the risks. ${ }^{232} \mathrm{~A}$ contradictory illustration of this essential requirement is provided within the judgment of Judge LJ in Dica, postulating a scenario where the risk may be concealed, and that a complainant may not be consenting to that risk. ${ }^{233}$ The position is further convoluted by Konzani, ${ }^{234}$ whereby Judge LJ stipulates that a complainant should be aware of the risks, and alternatively that the complainant can

\footnotetext{
${ }^{226} 720$ Ill. Comp. Stat. § 5/12-5.01; Mo. Rev. Stat. § 191.677 (2016)

${ }^{227}$ For examples see State $v$ Rick, 835 N.W.2d 478 (Minn. 2013); State v Weaver 939 S.W.2d 31656 Ark. App. 104 (1997)

${ }^{228} R$ v Dica [2004] EWCA Crim 1103; R. v Konzani [2005] EWCA Crim 706 [2005] 2 Cr. App. R. 14

229 ibid

${ }^{230} R$ v Dica [2004] EWCA Crim 1103

231 ibid [39]

232 ibid [39]

233 ibid [58]

${ }^{234}$ R. v Konzani [2005] EWCA Crim 706 [2005] 2 Cr. App. R. 14
} 
acquire the information from other sources. ${ }^{235}$ The former denoting an enhanced disclosure whilst the later demonstrates a basic disclosure.

In complete contrast with the English precedential vacillations, there is clarity surrounding basic disclosure in a number of jurisdictions within the United States, notably Arkansas ${ }^{236}$ and California. ${ }^{237}$ It is expressly stipulated that basic disclosure is the threshold requirement as the defendant is obligated to inform the prospective partner that they have the virus. ${ }^{238}$ The advantage of those particularised legal systems is that the provisions are unambiguous, provide certainty and a simplistic standardisation. The counterpoise is that the doctrinal difficulties that England faces are still operative, as it fails to denote that not all complainants will be able to make a fully informed decision.

The Canadian juridical precepts are similar to the aforementioned jurisdictions. However, the jurisprudence is unique and, therefore, paradoxically distinct to the U.S. States that require basic disclosure to consensual activity and the English position. ${ }^{239}$ Prima facie, the leading judgments endorse basic disclosure by expecting the defendant to disclose their sero-status to the complainant. ${ }^{240}$ This jurisdiction is dissimilar as disclosure of one's status is only required when there is a 'significant risk of harm' that poses a 'realistic possibility' of the virus being transmitted. ${ }^{241}$ The judiciary have endeavoured to provide guidance on when disclosure is required, but this is not extensive. ${ }^{242}$ It seems that the onus is on the defendant to evaluate the level of risk, and thereby excludes any consultation with the unsuspecting partner. This inculcates that the defendant is aware of the risk of the virus being transmitted, but the complainant may still be oblivious to that fact, thereby connoting that basic disclosure is the requirement.

\footnotetext{
235 ibid [44]

${ }^{236}$ Ark. Code Ann. § 5-14-123 (2017);

237 Cal. Health \& Safety Code § 120291 (2017);

${ }^{238}$ Ark. Code Ann. § 5-14-123 (2017); Cal. Health \& Safety Code § 120291 (2017)

${ }^{239} R$ v Dica [2004] EWCA Crim 1103; R. v Konzani [2005] EWCA Crim 706 ; Ark. Code Ann. § 5-14-123 (2017); Cal. Health \& Safety Code $\S 120291$ (2017)

${ }^{240}$ R. v. Cuerrier [1998] 2 SCR 371; $R$ v Mabior [2012] SCC 47

${ }^{241}$ R. v. Cuerrier [1998] 2 SCR 371; $R$ v Mabior [2012] SCC 47

${ }^{242} R$ v Mabior [2012] SCC 47
} 
Basic disclosure denotes that factual consent will be achieved, but there is no certainty that normative consent will always be attained. As previously noted, a significant minority of individuals seem to be unaware that the virus can be transmitted through unprotected intercourse. ${ }^{243}$ If one in five are uninformed as to the risk, it would signify that normative consent cannot be achieved on all occasions. If there is factual consent, but no consensus ad idem in terms of normative consent, then consent in a strict legal sense, cannot be fulfilled. There cannot be a fully informed consent. Any legislative framework must ensure that the constructional definitional elements of an acute awareness of the actual risk, on the part of the complainant are not only satisfied in practice, but reflected in new legislation.

Ohio And The Quasi-Enhanced Disclosure Model

Ohio appears to recognise a quasi-enhanced disclosure equipoise. ${ }^{244}$ The provision affords for a basic disclosure that will assist in exonerating a defendant. ${ }^{245}$ It does not anticipate that a basic disclosure will always provide a defence to the charge. Accordingly, there is also an inbuilt mechanism whereby basic disclosure will not suffice if the defendant becomes aware of, or ought to be aware that, the complainant is lacking the mental capacity to understand the risk associated with having unprotected sexual intercourse with an HIV+ individual. ${ }^{246}$ The provision invariably is concerned with capacity of the complainant rather than their knowledge, but in that circumstance it may still equate to an enhanced disclosure. The obligation to enhance that disclosure would come to prominence if a defendant became aware that the complainant did not understand that there are risks associated with unprotected intercourse with an HIV+ individual. ${ }^{247}$ This provision has the benefit of the simplification of basic disclosure where it can be ascertained

\footnotetext{
${ }^{243}$ National Aids Trust (n 74)

244 Ohio Rev. Code Ann. § 2903.11 (2016)

245 Ohio Rev. Code Ann. § 2903.11 (b)(1) (2014) (B) (1)

${ }^{246}$ Ohio Rev. Code Ann. § 2903.11 (b)(2)(2014)

${ }^{247}$ Ohio Rev. Code Ann. § 2903.11 (b)(2)(2014)
} 
that the complainant has provided a fully informed consent, that also embraces factual and normative elements of consent. It facilitates further disclosure when the complainant would otherwise be providing a legally deficient consent, as articulated above.

The provision augments any jurisdictional inclinations towards basic disclosure as it has the potential to take into account the 'significant minority'. ${ }^{248}$ The statute appears to focus upon the capacity of the complainant, rather than requisite knowledge of risk, but still implies that an enhanced disclosure may need to be expressed. There is an acceptance that the majority of individuals will be conscious of the risks. Furthermore, the constructional definitional elements of a fully informed consent are attained as the juncture of factual and normative consent could be absolute in all incidences of exposure. The soft paternal preferences of the provision permit the complainant's autonomy to be preserved on all occasions. A statute of this type should be welcomed, but the 'mental capacity' criterion should be superseded with an awareness of risk requirement on the part of the complainant. As this paper is based upon a subjective awarenesss of the defendant there are also concerns with facilitating an objective test for fact finder determination.

The Legal Systems That Expect An Enhanced Disclosure On All Occasions

Specific legislation that facilitates enhanced disclosure has taken a number of forms, and presented distinctive lexicon constructs as potential exemplars for other legal systems to follow. ${ }^{249}$ All of the highlighted enhanced disclosure templates emanate from the United States. They provide a more restrictive facility for the defence of consent to operate, and a more constrained exculpatory pathway, as there is an expectation that demands significantly more than disclosure of an individual's sero-

\footnotetext{
${ }^{248}$ National Aids Trust (n 74)

249720 Ill. Comp. Stat. § 5/12-5.01; Mo. Rev. Stat. § 191.677 (2016)
} 
status. Each State ${ }^{250}$ has enacted supplementary formulae that must be adhered to for the defendant's conduct to negate culpability.

All of these provisions place emphasis on the complainant having the opportunity to fully consent to the particular activity. In Illinois it is specified that disclosure anticipates more than the defendant divulging their status. ${ }^{251}$ For a fully informed consent of this persuasion there must be dissemination of HIV status and attendant risk. ${ }^{252}$ There are ambiguities as to what would equate to an 'action' but it may be presumed that the provision is referring to sexual activity. It would have been beneficial to have express wording to that effect within the provision.

.The provisions in a number of U.S. States specify that the complainant must be aware of more than the defendant's status for the defence of consent to be activated. ${ }^{253}$ The same cannot be iterated in English law where there is no conformity within the leading appellate judgments. It is not apparent whether a basic or enhanced disclosure will suffice for operation of the defence. Judicial precepts are opaque and are delineated more by mud rather than crystal. In Konzani, ${ }^{254}$ for instance, there seems to be focus on enhanced disclosure as there is an acknowledgement that the complainant must be aware that there are risks associated with unprotected intercourse with an HIV+ defendant. ${ }^{255}$ Unfortunately, there was no expansion of whether this should form a prospective template, and there are elements of Dica and Konzani that confusingly refer to basic disclosure as the touchstone. ${ }^{256}$ In those circumstances, it seems that it was presumed that the risks would be common knowledge. Further elucidation of the expectations of disclosure, as has transpired with the legislative provisions in the U.S. States that express 'consent' as the requirement, would provide clarification to domestic extant law.

\footnotetext{
250720 Ill. Comp. Stat. § 5/12-5.01; Mo. Rev. Stat. § 191.677 (2016)

251720 Ill. Comp. Stat. § 5/12-5.01

252720 Ill. Comp. Stat. § 5/12-5.01

${ }^{253} 720$ Ill. Comp. Stat. § 5/12-5.01; Mo. Rev. Stat. § 191.677 (2016)

${ }^{254}$ R. v Konzani [2005] EWCA Crim 706 [2005] 2 Cr. App. R. 14

${ }^{255}$ R. v Konzani [2005] EWCA Crim 706 [2005] 2 Cr. App. R. 14 [43]

${ }^{256} R$ v Dica [2004] EWCA Crim 1103[39]; ibid [44]
} 
There are certain impracticalities associated with facilitation of an enhanced disclosure template. Respective U.S. States infer that all complainants would be unaware of the risks that can be associated with unprotected intercourse with an HIV+ individual. It has been affirmed that four out of every five individuals are aware that the virus can be transmitted through unprotected sexual intercourse. ${ }^{257}$ It is not necessary to expect an enhanced disclosure on all occasions. If such a proposition is adopted, the onus is on the defendant to 'educate' the complainant on all occasions. This may be too burdensome a requirement for the operation of the defence. What would the defendant need to inform the complainant about? If this is the case then would the defendant need to be a statistician, or provide a portfolio of the substantive risks of transmission before a fully informed consent can be obtained? A preferred option would be to simply inform the complainant that they may risk becoming infected if they have unprotected intercourse with an HIV+ individual. There should be nothing else that needs to be disseminated by a defendant for the operation of the defence.

If disclosure is required then it must be a basic disclosure, unless it is obvious that the complainant does not appreciate that there is a risk that the virus may be transmitted. Anything more would be too onerous on the defendant. If there is to be a statutory provision on whether disclosure/consent can act as a defence then it needs to be constructed in this manner, reflecting the operative equipoise that has been highlighted in consideration of the review of comparative principles.

The Utilisation of Factual Consent Within The Jurisdictions

Whether the complainant has factually consented is obvious within all of the expectation levels of disclosure. The most disconcerting element is that factual consent is the prerequisite for basic disclosure. This cannot, and should not, be the

${ }^{257}$ National Aids Trust (n 74) 
case as a fully informed consent consists of two elements: factual consent and normative consent. ${ }^{258}$ If the complainant has only factually consented can they be said to have the applicable information to formulate an informed choice to run the risk of the virus being transmitted? An individual may have the desire to have unprotected intercourse with an HIV+ individual, but not have the appropriate awareness to authorise unprotected intercourse that runs the risk of the virus being transmitted. It must be reiterated that this will not be the situation in all cases as the majority of complainants will be fully conversant with the risks associated with unprotected intercourse with a person who has the virus.

England, Canada and a number of U.S. States' Penal Codes place emphasis on factual consent without true consideration of normative consent. This approach is devoid of rationality as the complainant who is unaware of the risk of transmission can never be said to have truly consented. Although they may have stipulated that they have agreed to intercourse with an individual who is HIV+, that is deficient for normative consent. The complainant must have agreed to intercourse with an HIV+ individual with the knowledge that there is a risk of the virus being transmitted. Beyleveld ${ }^{259}$ suggests that there can be no informational deficiencies if the defendant discloses their status. This neglects to take into consideration that a complainant may be unaware of the risks associated with unprotected intercourse with an HIV+ individual. It is also contrary to what Beyleveld had previously advocated when stipulating that to have knowledge and understanding the complainant's acceptance must be within their field of awareness. ${ }^{260}$ The latter proposal is the most appropriate as this conveys the significance of normative consent and rejects factual consent as the requisite threshold that the former proposition promotes.

The Utilisation of Normative Consent Within The Jurisdictions

\footnotetext{
${ }^{258}$ Westen (n 9)

${ }^{259}$ Brownsword Beyleveld, Consent and the Law (Oxford Hart 2007) 147

260 ibid 145
} 
In each jurisdiction basic disclosure pervades factual consent. However, not every circumstance that necessitates basic disclosure adheres to the proposed working definition of a fully informed consent. It is normative consent that is deficient as the 'significant minority' would not have the requisite knowledge to acquiesce to unprotected intercourse. ${ }^{261} \mathrm{~A}$ complainant must have the apposite levels of awareness that acknowledge that the defendant is HIV+ and that unprotected intercourse may result in the virus being transmitted. This would ensure that that individual is proficient to be able to make an informed decision that may affect their health and welfare. Only when factual and normative consent have been met may it be determined that the complainant has truly consented. This can be seen in a number of jurisdictions in the United States, but there is no clarification of normative consent in England and Canada.

Canada And England: The Utilisation Of Implied Consent

A further issue that needs to be addressed is the utilisation of an implied consent. The acceptance of an implied consent within extant English judicial precepts is akin to proclaiming that normative consent is irrelevant. The Canadian courts have gone to great lengths to exclude implied consent by adopting the jurisprudence that was set out in Ewanchuk, ${ }^{262}$ and ensuring that it applied to all forms of assault. ${ }^{263}$ This does not indicate that there has been an acceptance of the exclusion of an implied consent within Canada. Rawluck ${ }^{264}$ identified that, following the decision in Mabior, ${ }^{265}$ an implied consent transpires when there is no realistic possibility of transmission of the virus as the choice of whether to have intercourse with a HIV+ individual is removed from the complainant. ${ }^{266}$ An allowance of this magnitude would anticipate disclosure on all occasions, even when there was no risk of the virus being transmitted. The exclusion of an implied consent in Canada is in complete contrast to

\footnotetext{
${ }^{261}$ National Aids Trust (n 74)

${ }^{262} R v$ Ewanchuk [1999] 1 S.C. 330

${ }^{263} R v$ Williams [2003] 2 S.C.R. 134 [37]

${ }^{264}$ Rawluk (n135)

${ }^{265} R$ v Mabior [2012] SCC 47

${ }^{266}$ Rawluk (n135)
} 
how the law has developed in England where the decision in Konzani267 indicated that implied consent may be an available defence. ${ }^{268}$

In the majority of the U.S. States it can safely be assumed that consent must be an informed consent and that an implied consent would be deficient as the onus is on the defendant to disclose their status. Can there ever be an implied consent if the requirement of the statutory provision is enhanced disclosure? It appears that this cannot be the case. In Missouri, the court appeared to be unwilling to accept that the complainant may have acquired the knowledge from a third party. ${ }^{269}$ In State $v$ Yonts, ${ }^{270}$ the complainant testified that they had heard that the defendant had the virus but the court deemed such knowledge irrelevant. This denotes that implied consent is irrelevant, and follows the Canadian approach to this type of consent. A complainant cannot be said to have consented to the risk of transmission just because they had received information from a third party. The threshold requirement of a fully informed consent, and for that matter, normative consent, has not been satisfied in such a postulated hypothecate.

\section{An Optimal Pathway To Ensure That Normative Consent Is Achieved On All Occasions}

The respective jurisdictions have all endorsed consent or disclosure as a defence to the criminal transmission/exposure to HIV. It is the U.S. State provisions that anticipate more than a basic disclosure, and these provide real clarity of what equates to a fully informed consent. This does not denote that all of these statutes can be considered as the appropriate legislative framework. The statutes that require an enhanced disclosure fail to take into account that the majority of individuals will always be aware of the risk of the virus being transmitted; this should not be the

\footnotetext{
${ }^{267}$ R. v Konzani [2005] EWCA Crim 706 [2005] 2 Cr. App. R. 14

268 ibid[44]

${ }^{269}$ State v Yonts 84 S.W.3d 516, (Mo. Ct. App. 2002)

${ }^{270}$ State $v$ Yonts 84 S.W.3d 516, (Mo. Ct. App. 2002)
} 
appropriate threshold. A more suitable legal construct is a quasi-enhanced disclosure. This acknowledges that there are individuals who are unaware of the risks associated with unprotected intercourse. If such a situation arises, then the onus is on the defendant to inform that person that there is a risk of the virus being transmitted.

If there is to be a de novo legislative framework it is pertinent to assume that it should endeavour to provide a detailed extrapolation of how a fully informed consent can be attained. The suggested provision below corresponds with Robinson's proposal that criminal law defences can be compartmentalised into five categories, and that consent may be considered to be a defence that is within the ambit of 'offence modification' or 'failure of proof'. 271 The offence modification defence denotes that all elements of the offence have been completed and that the defence of consent is independent of the offence. ${ }^{272}$ Failure of proof denotes that, 'all of elements of the offence have not been proven'. ${ }^{273}$ Clause 1 (1) of the proposed offence denotes that consent would act as an offence modification defence as all elements of the offence would be satisfied, but the defendant should not be accountable as the complainant would be aware of the defendants status. ${ }^{274}$ Clause $1(2)$ of the proposed offence denotes that consent cannot act as a defence to that charge. A suggested provision should embrace the complainant's opportunity to provide a fully informed consent, and may resemble the recommended provision that is set out below:

1. It is a defence to a criminal charge of the transmission of HIV that the complainant consented to running the risk of acquiring the virus. For that person to consent to running the risk of acquiring the virus:

\footnotetext{
${ }^{271}$ Paul H Robinson, Structure and Function in Criminal Law, (Clarendon Press, Oxford 1997), 69

${ }^{272}$ Paul H. Robinson, 'Criminal Law Defenses: A Systematic Analysis' (1982) 82* Columbia law Review 199, 212

${ }^{273}$ ibid, 204

${ }^{274}$ Remove?
} 
(1)The defendant must disclose that he has the virus;

(2)That disclosure must take place before any unprotected sexual activity;

(3) The defendant must only partake in that activity if following disclosure he is confident that his prospective partner is aware that there is a risk that the virus may be transmitted

3. It is for the prosecution to establish that the complainant did not consent

4. Consent will not act as a defence if the defendant intended to transmit the virus or the complainant desired that he acquire the virus from that person.

The recommended statutory provision promotes consent as a defence to the charge of criminal transmission of HIV. It compels the defendant to furnish prospective sexual partners with all of the relevant facts before that person can acquiesce to unprotected sexual intercourse. Subsection (1) stipulates basic disclosure is the minimum pre-requisite. It is anticipated that basic disclosure would be sufficient in the majority of cases, and thus will fulfil the expectations of factual and normative consent. Subsection (2) confirms that the disclosure must take place before any restricted intimate acts. This is an essential provision as it prevents any ambiguity as to the timing of the disclosure. It is logical to presume that it must occur before any intimate acts as retrospective consent is normally precluded within the criminal law, and would be undesirable in this area.

Subsection (3) is reliant in part upon Ohio's provision as this quasi-enhanced disclosure template conflates basic and enhanced disclosure. The suggested statutory provision necessitates further disclosure when it becomes apparent to the defendant that the complainant is unaware of the risk of the virus being transmitted, thereby encompassing a subjective analysis at that juncture. ${ }^{275}$ The onus is on the defendant to explicate the relevant information. He would not be expected to go into the intricacies of the risks involved as this would be too onerous a task. An obligated

\footnotetext{
275 That corresponds to a liberal approach to criminal law
} 
defendant would, however, be expected to stipulate that there may be a risk that the virus can be transmitted. It is imperative that this section is inserted as it fulfils the obligation of normative consent, particularly as statistical information signifies that one in five do not understand that the virus can be transmitted via unprotected heterosexual intercourse. ${ }^{276}$ The burden of proof lies with the prosecution to establish lack of consent as any other requirement would unduly evade issues in relation to the right to a fair trial, ${ }^{277}$ and the presumption of innocence. ${ }^{278}$ The final element ensures that defendants who are intent on transmitting the virus would not be able to rely upon a consenting complainant. This would also denote that 'bug chasers' could not consent to running the risk of the virus being transmitted as the impacted issue is constitutionally an affront to public policy imperatives in this substantive arena. ${ }^{279}$

The provision would ensure that the complainant has had adequate opportunity to assess whether they desire to participate in unprotected intercourse with a HIV+ individual whilst knowing that there are risks involved. This does not denote that consent or disclosure may be the only defence that is available to HIV+ individuals. A defendant using a condom, partaking in low risk activities or having a undetectable viral load may also act as potential defences. ${ }^{280}$

\section{Concluding Remarks: A Consent Must Be A Fully Informed Consent}

The judicial precepts in England did not clarify the extant circumstances of a fully informed consent. A defendant disclosing their status was deemed to be an

\footnotetext{
${ }^{276}$ National Aids Trust (n 74)

${ }^{277}$ Convention for the Protection of Human Rights and Fundamental Freedoms (European Convention on Human Rights, as amended) (ECHR) Art 6

${ }^{278}$ Woolmington $v$ DPP [1935] AC 462

${ }^{279}$ Weiss (n 204), 398

${ }^{280}$ Hughes, David and Reed, Alan (2016) Criminalisation of HIV Transmission: Anglo-North-American Comparative Perspectives and

Optimal Reforms to Failure of Proof Defences. In: Legal Perspectives on State Power: Consent and Control. Cambridge Scholars Publishing 
adequate disclosure. This reinforced the presumption that the extant position in England was more inclined to factual consent than normative consent. The inspection of Canada and America identified that there was no uniform approach to consent. There were three distinct methods adopted by legislators and the judiciary: basic; quasi-enhanced; and enhanced disclosure. It was found that a number of jurisdictions had adopted an approach that necessitated the defendant disclosing their HIV status before the complainant would partake in unprotected sexual intercourse. Other jurisdictions had approached the issue by anticipating that disclosure of ones' sero-status may be sufficient, but there may be circumstances whereby the defendant may need to inform their prospective sexual partner of the risk of infection through unprotected intercourse. The final categorisation signified that a defendant must inform the complainant of their status and the risk of the virus being transmitted.

Basic disclosure denotes that factual consent will be achieved on all occasions, but the deficiencies of facilitating a limited obligation on the part of the defendant are evident. There is no certainty that normative consent will always be attained. There is, however, certainty of normative consent identified within a number of U.S. State laws. ${ }^{281}$ The investigation identified that disclosure of HIV status, and the risk therein, were pre-requisites for the defence of consent to operate. It is evident that this requirement fulfils the obligation of a fully informed consent, but does not articulate the most pertinent approach, as the majority of individuals would already be aware of the risks of intercourse with an HIV+ individual.

${ }^{281}$ Ohio Rev. Code Ann. § 2903.11 (B) (2) (2016) 
Ohio's provision identifies that a basic disclosure may be adequate. This did not denote this is always the requirement as the provision may expect an enhanced disclosure if the circumstances dictate this facilitation. ${ }^{282}$ It is with that in mind that the suggested statutory provision adopted the same elements. It is propounded that the most appropriate route to construct an optimal legislative framework is via a template that provides for basic and enhanced disclosure, a quasi-enhanced disclosure. This takes into consideration that the majority of individuals would be aware of the risk of sexual intercourse with an HIV+ defendant, and provides an effective consent on all occasions. 